\title{
SÉRÜLÉKENY IDENTITÁS A KOLLEKTÍV ÁLDOZATI TUDAT PSZICHOLÓGIAI HATÁSAI ${ }^{1}$
}

\author{
MÉSZÁROS NOÉMI ZSUZSANNA ${ }^{1,2}$ - VÁMOS ESZTER ${ }^{3}$ - \\ SZABÓ ZSOLT PÉTER ${ }^{4}$
}

\author{
${ }^{1}$ PTE BTK Pszichológia Intézet Szociál- és Szervezetpszichológia Tanszék \\ ${ }^{2}$ PPKE BTK Pszichológia Intézet Szociál- és Szervezetpszichológia Tanszék \\ ${ }^{3}$ PTE BTK Interdiszciplináris Doktori Iskola \\ ${ }^{4}$ ELTE PPK Pszichológia Intézet Szociálpszichológia Tanszék \\ E-mail: meszaros.noemi@pte.hu
}

Beérkezett: 2016. június 1. - Elfogadva: 2017. február 11.

Online megjelenés: 2017. június 27.

Tanulmányunkban a kollektív áldozati tudat nevú jelenség magyar nyelvü összefoglalóját kívánjuk nyújtani. Kollektív áldozati tudatról akkor beszélünk, ha egy csoport tagjai között nagyjából egybehangzóan osztott az a vélekedés, hogy a saját csoport egyszeri vagy akár sorozatos támadásoknak volt kitéve más csoportok által. Ezeket a támadásokat, amellett, hogy nem megérdemeltnek és igazságtalannak ítélik meg, olyan, a moralitás szabályait figyelmen kívül hagyó szándékos károkozásnak tartják, melyek bekövetkeztét a csoport nem volt képes megakadályozni, ezért kiszolgáltatottnak érzi magát. Ez a fajta identitáskonstruálás nemcsak a saját csoport belsố müködésére és jövôjére, hanem más csoportokkal való kapcsolataira nézve is jelentốs hatással van.

A jelenség ismertetése során kitérünk a fogalom meghatározásával és operacionalizálásával kapcsolatos problémákra. Bemutatásra kerülnek a csoportszintû áldozattá válás tapasztalatát meghatározó dimenziók, a történelmi viktimizáció eredményeképpen létrejött kollektív áldozati identitás fenntartásának és továbbadásának módjai; emellett az áldozati identitáskonstruálás jelenségének funkciói, valamint destruktív és - lehetséges - konstruktív következményei is. Végezetül, a magyar történelmi pálya sajátosságaiból eredeztethetô áldozati identitásállapot jellemzôit tárgyaljuk az elmúlt évek/évtizedek magyar társadalomtudományi kutatásai és elmélkedései alapján.

Kulcsszavak: észlelt kollektív áldozati tudat, nemzeti identitás, exkluzív - inkluzív áldozati tudat, versengó áldozatiság

${ }^{1}$ A tanulmány megírását az OTKA K 109009 számú pályázata, valamint az MTA Sasakawa Young Leaders Fellowship Fund támogatta. Illetve ezúton szeretnénk megköszönni a kézirat anonim bírálóinak az értékes észrevételeit és javaslatait, melyek nagymértékben hozzájárultak a tanulmány végsố változatának létrejöttéhez. 


\section{BEVEZETÉS}

A csoportközi agresszió és konfliktus témája mindig is központi jelentôségú volt a szociálpszichológia számára (pl. Sherif, 1956; Sherif, Harvey, White, Hood és Sherif, 1961; Tajfel, 1982). Az 1990-es évek végétôl elôtérbe kerültek azok a kutatások, amelyek a saját csoport által a múltban vagy a jelenben elkövetett agressziónak a csoport identitásával való kapcsolatát vizsgálták. Ezek a kutatások a csoportidentitást több oldalról közelítették meg: egyrészrốl mint kiindulópont, másrészrôl mint kimenetel. Ez alapján a csoporttal való azonosulás különbözô módjai egyik oldalról az események értelmezését befolyásoló tényezôkként jelentek meg (pl. Leach és mtsai, 2008; Roccas, Klar és Liviatan, 2006), másik oldalról a kutatók hangsúlyozták az elkövetett agresszió identitásra gyakorolt következményeit is (Kessler és Hollbach, 2005). A saját csoport által elkövetett agresszió pszichés hatásainak vizsgálatában kiemelt jelentốséget kaptak az olyan csoportalapú érzelmek, mint a bûntudat, a szégyen, a harag, a sajnálat, az empátia és a szimpátia (összefoglalóan magyarul errôl Szabó, Banga, Fülöp és László, 2011; Szabó, 2013). A terület kutatóit egyesítette az a kérdés, hogy mi történik a múltban vagy a jelenben agressziót elkövetố csoportok tagjaival: milyen identitást formálnak az agresszió élményébő́l, ehhez milyen érzelmek kapcsolódnak, illetve adott esetben milyen morális igazolások segítségével kerülhetik el a szembenézést az elkövetett rossz tettekkel kapcsolatban? Ezek a kutatások széles spektrumon mozogtak, rímelve a nyugati nemzetek ellentmondásos történelmére. Vizsgálták például a ma élố németek reakcióit a holokausztra (Dresler-Hawke és Liu, 2006), a gyarmatosító népek különbözô generációinak vélekedését a gyarmatosításról (Doosje, Branscombe, Spears és Manstead, 1998; Licata és Klein, 2010), valamint a többségi társadalom kapcsolatát a leigázott ôslakosokkal (McGarty, Pedersen, Leach, Mansell, Waller és Bliuc, 2005). Ezeket a kutatásokat összefoglalva Licata és Klein (2010) Pascal Bruckner francia filozófusra hivatkozva felvetik, hogy a kollektív búntudat átélése a nyugati népek számára az utóbbi évtizedekben normává vált. A megbánás és a bûntudat kultúrájában élünk (Barkan, 2000; Bruckner, 2010; Paez, 2010), amelyben a korábbi elkövetôk úgy próbálják helyreállítani a pozitív morális identitásukat, hogy mindenki másnál jobban igyekeznek elismerni az általuk elkövetett rossz tetteket (Licata és Klein, 2010).

Miközben a korábbi agresszor nemzetek szociálpszichológusai az agresszió identitásra gyakorolt hatásával voltak elfoglalva, kevés figyelem irányult a magukat áldozatnak tartó csoportok ma élô tagjaira: bár már Bar-Tal és Antebi 1992-ben írt mindkét cikkükben azzal foglalkoztak, hogy pszichésen milyen hatása van a szubjektív kollektív áldozati élménynek, mégis ennek a kérdésnek a szisztematikus kutatása az empirikus szociálpszichológia csak jóval késôbb, a 2000-es évek végén kezdôdött meg.

2009-ben jelent meg az izraeli kutató, Daniel Bar-Tal és munkatársainak (Bar-Tal, Chernyak-Hai, Schori és Gundar, 2009) észlelt kollektív áldozati tudatról írt összefoglaló tanulmánya, amely már konkrétan azzal a kérdéssel foglalkozott, hogy miként befolyásolja az áldozattá válás szubjektív élménye a csoport identitását, kollektív pszichéjét és más csoportokkal való kapcsolatát. Ezt követốen egyre több szociálpszichológus kezdett el ezzel a kérdéssel foglalkozni (errôl áttekintést nyújt Vollhardt, 2012). A téma aktualitását bizonyítja az is, hogy Európa egyik vezetố szociálpszichológiai folyóirata, a European Journal of Social Psychology 2016-ban külön szekciót szentel a témá- 
nak, „Hogyan válaszolunk arra, ha egy másik csoport rosszat tesz velünk: értelemadás a kollektív áldozattá válásnak” címmel. Összefoglalónkban mi ennek a kutatási vonalnak az eredményeit kívánjuk bemutatni: hogyan alakul ki az észlelt kollektív áldozati identitás, hogyan marad fenn, milyen következményei vannak, és mennyiben releváns ez a kérdés a magyar kontextusban.

Az összefoglaló elsố részében bemutatjuk az általunk használt fogalmakat ${ }^{2}$, valamint az ezekkel a fogalmakkal kapcsolatos kérdőjeleket, vitás kérdéseket.

\section{ÉSZLELT KOLLEKTÍV ÁLDOZATI IDENTITÁS FOGALMI MEGHATÁROZÁSA}

A kollektív áldozatiság konceptualizálása és pszichológiai szempontú meghatározása érdekében először is érdemes különbséget tenni az objektív tapasztalatok és a szubjektív élmények szintjei között (Vollhardt, 2012). Annak, hogy egy csoport áldozatként definiálhassa magát, azaz szubjektív állapotát tekintve áldozati identitást alakítson ki, objektív szempontból elôfeltétele, hogy valamilyen erôszak elszenvedôje legyen. Ez alatt az Egészségügyi Világszervezet (WHO, 2002) megfogalmazása alapján olyan szándékos agresszív cselekedeteket értünk, melyeket egy adott csoport tagjai követnek el egy másik csoport ellen azért, hogy politikai, gazdasági vagy szociális céljaikat elérjék. Az etnopolitikai célok érdekében véghezvitt erôszakos cselekményeket rendszerezve Suedfeld (1999) a kollektív agresszió számos formáját különbözteti meg: a csoportok közötti fegyveres összecsapásokon túl ide sorolhatók a kitelepítések, a megszállás, a terrorizmus, a népirtás, de akár olyan állam által elkövetett tettek is, mint az elnyomás, a kínzások, az emberek eltüntetése, illetve az emberi jogok bármilyen figyelmen kívül hagyása. Ugyanakkor áldozattá válni nem kizárólag erőszakos cselekedetek kapcsán lehetséges, a kifejezést olyan csoportokra is használják, amelyek egy adott társadalmon belül fennálló strukturális okokból kerülnek előnytelen helyzetbe (pl. diszkrimináció rassz vagy nemi hovatartozás alapján; ld. Sullivan, Landau, Branscombe és Rothschild, 2012). Mi több, emberi tényezók sem feltétlenül szükségeltetnek hozzá: egy csoportot természeti katasztrófák (pl. cunami) is sújthatnak (Vollhardt és Staub, 2011). A csoportszintû áldozattá válás tehát számos, egymástól esetenként jelentôsen eltérô kontextusban lehetséges. Összefoglaló tanulmányában Vollhardt (2012) több olyan dimenziót jelöl meg, amelyek segíthetnek differenciálni az áldozattá válás megannyi formája között. A kontextuson túl az események idôbeli folytonossága (egyszeri traumatikus esemény vs. idôben elhúzódó), gyakorisága (egyszeri esemény vs. többször ismétlődô), idôbeli távolsága (múltbéli esemény vs. a jelenben is tartó), az agresszorok száma (egy agresszor csoport vs. több agresszor csoport) mind-mind az áldozati tapasztalatok objektív szempontú megkülönböztetéséhez adnak támpontokat. Az 1. táblázatban összefoglaljuk az áldozattá válás tapasztalatát meghatározó dimenziókat.

\footnotetext{
${ }^{2}$ Összefoglalónkban az észlelt kollektív áldozati tudat, az észlelt kollektív áldozati identitás és az észlelt kollektív áldozatiság kifejezéseket a téma nemzetközi szakirodalmának megfelelốn szinonimaként fogjuk használni, miközben késôbb bemutatjuk, hogy a kollektív áldozati tudat valójában a kollektív áldozati identitás „magja”.
} 
1. táblázat. Az áldozattá válás tapasztalatát meghatározó dimenziók

\begin{tabular}{l|l}
\hline Dimenziók & \multicolumn{1}{c}{ A dimenzió tartalma } \\
\hline Az áldozattá válás kontextusa & - Természeti katasztrófa \\
& - Hátrányos megkülönböztetettség \\
& - Megszállás \\
& - Kitelepítések \\
& - Fegyveres összecsapások \\
& - Terrorizmus \\
& - Népirtás \\
\hline Idốbeli folytonosság & - Egyszeri traumatikus esemény \\
& - Idôben elhúzódó \\
\hline Az események gyakorisága & - Egyszeri esemény \\
& - Ismétlődó, többszöri \\
\hline Az események idóbeli távolsága & - Múltbeli, lezárult \\
& - Jelenben is tart, nem zárult le \\
\hline Az agresszorok száma & - Nincs agresszor csoport, természeti \\
& katasztrófa okozta az áldozati élményt \\
& - Egy agresszor \\
& - Több agresszor csoport \\
\hline
\end{tabular}

Vollhardt (2012) szerint azért fontos különbséget tennünk ezek között a formák között, mert mást jelent például közvetlenül fizikai áldozattá válni egy folyamatosan tartó, lezáratlan konfliktusban, mint áldozatnak megélni magunkat évszázadokkal ezelôtt történt események miatt. A szociálpszichológia számára az lesz igazán érdekes, hogy az objektív események a különbözô megpróbáltatásokat elszenvedô csoport szubjektív élményvilágában hogyan képezôdnek le, milyen jelentést kapnak, illetve milyen kognitív, érzelmi és viselkedéses következményekhez - végsố soron pedig milyen identitás megkonstruálásához vezetnek.

Annak érdekében, hogy megalapozott empirikus kutatásokat lehessen végezni ezen a területen, fontos a használt fogalmak tisztázása. Jelen pillanatban gondot okoz, hogy a csoportközi viszonyok áldozataival foglalkozó szakirodalom - ahogy láthattuk - sokszor ugyanazzal a kifejezéssel illet egymástól eltéró jelenségeket, miközben elôfordul az is, hogy több kifejezést használ hasonló tartalmú jelenségek megnevezésére. Ahogyan Vollhardt (2012) felhívja rá a figyelmet, a kollektív áldozati identitás fogalomkörén belül a kutatók különféle terminológiákkal kísérlik megragadni az áldozati vélekedések különböző - ugyanakkor természetesen részben átfedô - aspektusait. Bar-Tal és munkatársai (2009) észlelt kollektív áldozatiságnak nevezik azt a csoporttagok által nagyjából egybehangzóan osztott vélekedést, amikor egy csoport úgy észleli, hogy sorozatos támadások és megpróbáltatások érik. A csoport úgy ítéli meg, hogy az agresszorok célja a szándékos károkozás, amelyre a saját csoport nem szolgált rá. A csoportot érô erôszak igazságtalan és morálisan nem elfogadható, a csoport pedig kontrollt veszít, kiszolgáltatottá válik: a csoporttagok úgy érzik, hogy nem képesek megakadályozni a történéseket. Ez a fajta vélekedésrendszer - vagy más szavakkal identitás állapot - pedig jelentôs következményekkel jár nemcsak a saját csoport belsó múködésére, de a csoportközi kapcsolatokra nézve is. Bar-Tal és munkatársai (2009) az észlelt kollektív áldozatiság koncepcióján túl, Lifton (2003) a totális áldozatiság, 
Schori, Klar és Roccas (2009) az áldozati orientáció, Vollhardt (2009a) pedig az inkluzív versus exkluzív áldozati tudat fogalmai mentén igyekszik megközelíteni a jelenséget (ezekrôl a késôbbiekben még szót ejtünk). Ide tartozik továbbá a Bar-Tal és Antebi (1992a, 1992b) által leírt „ostromlott erôd” mentalitás is, amelynek lényege, hogy a csoport teljesen magára hagyatva érzi magát egy erôszakos világban, ahol idegen csoportok negatív viselkedéses szándékokkal rendelkeznek iránta. Egyfajta általános bizalmatlanságnak - sốt gyanakvásnak - köszönhetôen a csoport úgy érzi, az egész világ ellene van, ártani akar neki. Mindezek mellett, az észlelt kollektív áldozati szereppel kapcsolatos terminológia fontos részét képezi két további kifejezés: a versengó áldozatiság (Noor, Brown, Gonzalez, Manzi és Lewis, 2008; Noor, Shnabel, Halabi és Nadler, 2012) és a duális szerepek (Simantov-Nachlieli és Shnabel, 2014) koncepciója. A Noor és munkatársai $(2008,2012)$ által megfogalmazott versengó áldozatiság annak megnevezésére szolgál, amikor az egymással szemben álló csoportok tagjai minden erôfeszítést megtesznek annak érdekében, hogy kinyilatkoztassák és elismertessék, hogy a saját csoportjuk több igazságtalanságnak és szenvedésnek volt kitéve, ezáltal nagyobb áldozata az eseményeknek, mint a másik csoport. Ez az áldozati szerepért folytatott harc azonban tovább mélyíti a két csoport közötti konfliktust, hiszen saját sérelmeik felnagyításával leértékelik, sốt megkérdőjelezik a másik fél szenvedéseinek súlyosságát. Egyben a másik fél felelősségének tekintik azt is, hogy nem tesz lépéseket a csatározások békés megoldásának irányába. A versengó áldozatiságnak két nagyobb típusa ismert. Versengó áldozatiságnak nevezzük egyrészt, amikor az egymással konfliktusban álló felek harcolnak azért, hogy ki a konfliktus „igazi áldozata” (pl. a katolikus vs. protestáns írek; Noor, Brown és Prentice, 2008), másrészt, amikor ugyanazon agresszor áldozatai versenyeznek egymással azon, hogy ki szenvedett többet az agreszszor lépéseinek következtében (pl. a nácik agressziója esetén a zsidó és a roma csoport tagjai, Noor és mtsai, 2012).

Noor és munkatársai (2012) a versengő áldozatiság kapcsán a szenvedések fizikai, anyagi, kulturális, pszichológiai, valamint legitimitás dimenzióját különböztetik meg. Az elszenvedett sérelmek fizikai dimenzióját tekintve a csoportok között abban alakul ki verseny, hogy objektív mennyiségi szempontokat figyelembe véve próbálják meghatározni, hogy melyik fél a nagyobb áldozata az eseményeknek, azaz melyik oldalon magasabb a kioltott emberéletek száma. A versengéshez hozzátartozik persze az is, hogy eleve más súllyal esik latba az egymással szembenálló oldalakon elvesztett emberéletek értéke is; a saját csoport tagjának élete többet ér, mint a másik csoport tagjáé, még akkor is, ha elóbbi a harcokban részt vevô katona, utóbbi pedig ártatlan civil. A materiális dimenzió az anyagi erôforrások egyenlôtlen elosztásából fakadó hátrányos megkülönböztetettség érzését - értve ez alatt akár egy társadalmon belül egyes csoportok szociális és politikai ügyekben (pl. lakhatás, oktatás, foglalkoztatottság) történô diszkriminációját -, illetve az ebbôl eredô csoportok közötti konfliktusokat jelöli. A kulturális dimenzió pedig azt az általános fenyegetést foglalja magában, ami egy csoport világlátását vagy életmódját - például az adott társadalom örökségét, identitását, nyelvét, vallását, hagyományait, értékeit és normáit - érheti a másik csoport részérôl. A pszichológiai dimenzió az áldozattá válásból fakadó pszichés distresszt és emocionális megpróbáltatásokat, valamint a fenyegetettség és bizalmatlanság érzéseit öleli fel. A legitimitás dimenzióját pedig röviden úgy lehetne leírni, aminek középpontjában az 
átélt és okozott sérelmek indokolhatósága áll. Itt az áldozati versengés a saját csoport által elszenvedett agresszió igazságtalanságának, valamint a saját csoport által elkövetett erôszakos cselekedetek igazolhatóságának bizonyítása körül zajlik.

A kollektív áldozatiságért való versengés mellett azok a helyzetek is külön figyelmet érdemelnek, ahol egy csoport tagjai egyszerre élik meg azt, hogy csoportjuk agresszor és áldozat is volt a szituációban. Simantov-Nachlieli és Shnabel (2014) duális szerepnek hívja ezt a jelenséget; és Nadler és Shnabel (2008; Shnabel és Nadler, 2008) szükségletalapú modelljéból indulnak ki: eszerint míg az agresszornak arra van szüksége, hogy a pozitív morális identitását állítsa helyre, az áldozatnak sokkal inkább arra, hogy visszanyerje cselekvóképességét, ágenciáját, erejét. A duális szerepet felvevó csoportok esetében az agresszor szerep és az áldozat szerep más-más jellegú viselkedést motivál: az agresszor szerep a megbánás és a jóvátétel felé, míg az áldozat szerep az erô visszanyerése felé (pl. a bosszú segítségével). A kezdeti eredmények azt mutatják, hogy a duális szerepet felvevô csoportok inkább az áldozatokra hasonlítanak viselkedésükben, és a negatív következmények kerülnek elôtérbe. Az izraeli-palesztin konfliktus kontextusában gyújtött korrelációs adatok azt mutatják, hogy míg az „erôs Izrael” szükséglete - ami áldozati hiedelmekbôl fakad - antiszociális tendenciákhoz vezetett a palesztinokkal szemben, addig a „morális Izrael” szükséglete nem vezetett erôteljesebb proszociális tendenciákhoz (Simantov-Nachlieli és Shnabel, 2014). Simantov-Nachlieli és Shnabel szerint ezek a kezdeti eredmények segíthetnek megmagyarázni, hogy a feloldhatatlannak tûnô konfliktusokban hogyan újul ki újra és újra az erôszak: hiszen az egyszerre agresszor és áldozat csoportok esetében a bosszú nagyobb valószínúséggel jelenik meg, mint a helyreállító viselkedés, mindez pedig a konfliktus eszkalációjához vezet.

A kollektív áldozatiság különbözô megközelítéseinek ismertetése után innentôl kezdve tanulmányunkban mi elsôsorban a kollektív áldozattá válásnak egy specifikus formájával foglalkozunk: a múltbéli eseményekhez kötôdó történelmi viktimizációval. Arra vagyunk kíváncsiak, hogy a csoport történelmében fellelhetô áldozati élmények milyen pszichés hatással vannak a csoport ma élô tagjainak életére, valamint hogy a történeti áldozatiság miként adódik át generációról generációra, milyen következményekkel jár, és hogy lehetséges-e a feloldása.

\section{HOGYAN ALAKUL KI ÉS HOGYAN ADÓDIK TOVÁBB A TÖRTÉNELMI VIKTIMIZÁCIÓ EREDMÉNYEKÉPPEN LÉTREJÖTT KOLLEKTÍV ÁLDOZATI IDENTITÁS?}

\section{A kollektív áldozati identitás megkonstruálása}

A kollektív áldozati identitás létrejöttében az események valódi bekövetkezése mellett a szubjektív észlelés, mi több, társas konstrukciós folyamatok is kulcsszerepet játszanak. A csoport bizonyos szempontból maga hozza létre a történtek közösen osztott reprezentációját: ezzel nem csupán kijelöli a szerepeket - önmagát áldozatként, a külsố csoportot pedig elkövetôként ábrázolva -, hanem közös valóságot és identitást is teremt a csoport tagjai számára. A történelem reprezentációjának képlékenysége 
nemcsak adott események leírásában és értelmezésében, de akár már azok jelentôségteljesként való kiválasztásában is megnyilvánulhat. A történelem eszerint nincs kóbe vésve, a nemzeti emlékezet funkcionális és szelektív: a múlt társas reprezentációja bizonyos szempontból a jelen érzelmi és kognitív szükségleteinek megfelelôen történik (László, 2003), majd ha egy következô nemzedék saját jelenének igényei úgy kívánják, ismét újrakonstruálásra kerül (Csepeli, 1992, 2013a). Rimé, Bouchat, Klein és Licata (2015) szerint például, ha a minket körülvevố társas valóság változásai megkívánják, az új generáció tagjai akár a gondos szocializáció (ennek módjai lentebb kifejtésre kerülnek) ellenére is új, a korábbi generációk reprezentációitól eltérô reprezentációkat fognak kialakítani a múltról.

A történelem társasan konstruált jellege bizonyos esetekben abban érhetô tetten, hogy a múlt eseményei közül egy-egy vereség és kudarc lesz az, aminek a csoport kitüntetett szerepet tulajdonít, és amely így identitásának központi elemévé válik. A traumatikus, szélsôséges élmények megfelelő alapanyagul szolgálnak a kollektív emlékezet számára, ezek könnyen elmesélhetô, narrálható események, amelyek megmutatják a csoport tagjainak a világban betöltött helyüket, és más csoportokkal való viszonyukat (Liu és László, 2007). A pszichoanalitikus megközelítéssel dolgozó Volkan (2001, 2006) „választott traumákról” beszél, vagyis a múlt traumatikus eseményeinek - más csoportokkal való konfliktusok, veszteségek, megaláztatások - közösen osztott mentális reprezentációiról, amelyeket a múlt generációi nem voltak képesek elgyászolni és feldolgozni; a más csoportok által okozott narcisztikus sérülést nem tudták helyrehozni. Így ezek a sérelmek lesznek azok, melyek generációkon átívelve öröklődnek, és a kollektív emlékezet részévé válva a csoport élményvilágának központi elemévé válnak. Volkan szerint a „választott” trauma kifejezés valójában a csoport egyfajta tudattalan választását jelöli, melynek következtében a történelem során elszenvedett traumák közül valamilyen szempontból jelentôsnek ítéltetik és kiválasztásra kerül néhány esemény, mely aztán a csoport történelmének integráns elemeként megôrzésre kerül. Ilyen választott trauma a kínaiak esetében az 1937-es nankingi mészárlás, a zsidók számára a holokauszt, a palesztinok 1948-as katasztrófája, vagy a magyarok számára az 1526-os mohácsi csatavesztés.

A történelmi emlékezet és a csoportidentitás kapcsolatát egyfajta kölcsönös egymásra hatás jellemzi (pl. Alexander, Eyerman, Giesen, Smelser és Sztompka, 2004; Connerton, 1989; Kurtis, Adams és Yellow-Bird, 2010; Nora, 2010; Ricoeur, 2006). A történelem szociális reprezentációja nemcsak a csoportszintú identitáskonstruálásban játszik szerepet, de az egyének csoporttal való azonosulásának mértékére és módjára is befolyással van (Liu és Hilton, 2005); miközben az azonosulás ugyanígy hatással van a történelmi események észlelésére és értelmezésére: a pozitív csoportidentitás megôrzése érdekében sokszor akár torzítják is a múltat, például egyes negatív múltbeli események elhallgatásával vagy átértelmezésével (Baumeister és Hastings, 1997). Sahdra és Ross (2007) például azt találták, hogy minél inkább azonosul valaki a csoportjával, annál kevésbé idéz fel olyan eseményeket, amelyben a saját csoport elkövetốként vett részt. Az azonosulás és az áldozati események felidézése között azonban nem találtak ilyen jellegú kapcsolatot. Egy latin-amerikai és fehér amerikai egyetemista mintán végzett longitudinális vizsgálatban ugyanakkor Thomsen és munkatársai (2010) azt kapták, hogy az etnikai azonosulás mértéke bejósolta az etnikai alapú ál- 
dozattá válás észlelését három évvel késôbb. Bilali (2012) szerint a csoport áldozattá válásával és agressziójával kapcsolatos történelmi emlékezet - az események felidézése és értékelése - az azonosulás különbözô dimenzióival mutat kapcsolatot. Eredményei alapján, míg a saját csoport felsôbbrendûségének érzése (mint a glorifikáció aldimenziója, lásd errôl részletesebben Roccas, Sagiv, Schwartz, Halevy és Eidelson, 2008) a csoport által elkövetett agresszióval kapcsolatos reakciókat jósolta be, addig a csoportidentitás személyes fontossága, azaz a szelf-koncepcióban betöltött központi volta (mint a kötôdés aldimenziója, Roccas és mtsai, 2008) a saját csoport áldozattá válására adott reakciók prediktora volt. Magyar mintán végzett vizsgálatukban Mészáros, Szabó és László (2013) eredményei is azt igazolják, hogy a nemzettel való azonosulás módja hatással van a történelmi események értékelésére: miközben abban nagyfokú egyetértés mutatkozott, hogy melyek a magyar történelem fontos eseményei, és ezek milyen valenciával rendelkeznek, az értékelések intenzitásában különbség volt tapasztalható. A glorifikáló azonosulásban (ez a saját csoport felsôbbrendúségét hirdeti, szemben a csoporttal való érzelmi kapcsolódást mérô kötôdés dimenziójával) magasabb pontszámot elérôk másokhoz képest a csoporttal történt traumatikus eseményeket negatívabban, míg a dicsôséges eseményeket pozitívabban értékelték. Kovács és Pántya (2012) kutatásukban pedig azt kapták, hogy a magyar történelmi pálya negatív szemléletét - egyebek mellett - a patriotizmus mérsékli: a patrióták a pozitív történelmi eseményeket eredményesebbnek, a történelmi pályát pedig kevésbé hanyatlónak látják.

\section{A kollektív áldozati identitás továbbörökitésének módjai}

A kollektív áldozati identitás létrejöttéhez nem fontos, hogy egy csoport jelenleg élő tagjai közvetlenül erôszakosság elszenvedôi legyenek. A közös csoportba tartozás és a csoporttal való azonosulás (Tajfel, 1982; Turner, Hogg, Oakes, Reicher és Wetherell, 1987), illetve az észlelt kontinuitás a csoport jelenlegi és múltban élô tagjai között (Sani és mtsai, 2007) elegendô lehet ahhoz, hogy az incidensekben közvetlenül nem érintett csoporttagok is a sajátjukként éljék meg a veszteségeket. A csoporttal való azonosulás mértéke szerepet játszik abban, hogy a csoport múltbeli áldozattá válása milyen személyes relevanciával bír az egyén számára (Pennekamp, Doosje, Zebel és Fischer, 2007). A csoport korábbi generációi által átélt erôszakos konfliktus különbözô társas és transzgenerációs átöröklődési mechanizmusok révén nyomot hagyhat a leszármazottak identitás-mintázataiban.

Miként marad fenn ez az áldozati szerep, hogyan adódik tovább generációról generációra? A választott traumákat, a csoportközi agressziót, a szélsôséges szenvedés epizódjait a csoport a kollektív memóriájában tárolja (Staub és Bar-Tal, 2003). Hammack (2009) „mesternarratívának” nevezi azt a múltbéli konfliktusról kialakított, a társadalom széles körében osztott uralkodó diskurzust, mely az oktatási, kulturális, politikai és szociális mechanizmusok révén gyökerezik mélyen a csoport identitásában, és a következô generáció tagjai már igen korán szocializálva vannak az elsajátítására.

A generációról generációra történô átadás egyszerre több szinten valósul meg: társadalmi-intézményesült szinten és a személyközi kommunikáció formájában (Olick és Robbins, 1998). A társadalmi, makroszintú átadás az iskolában kezdôdik a történelem- 
könyvek, zenék, versek és iskolai ünnepélyek formájában (Adwan, 2001; Goodman és Mizrachi, 2008; László, 2005, 2012; Lomsky-Feder, 2004; Tóth, Vincze és László, 2006). Szintén a társadalmi szinthez tartoznak a megemlékezések (Khalili, 2008), a múzeumok (Crownshaw, 2007), az emlékhelyek (Feldman, 2007) és a politikai beszédek (MacDonald, 2003; Stern, 1995). Ide sorolható a média is: például a filmek (Bar-Tal és Antebi, 1992b), a rádióadások (Bilali és Vollhardt, 2013), de a szépirodalom (Tamari, 2002; Vincze és Kôváriné Somogyvári, 2003) is. A kollektív trauma átadásának közvetlenebb módjai az idősebb családtagok által elmondott történetek (Khalili, 2007; Vollhardt, 2012), valamint a családok által közvetlenül ôrzött tárgyi emlékek. Vollhardt (2012) írja le például, hogy az 1948-ban elúzött palesztin családok közül sokan megtartották régi házuk kulcsait, mintegy emlékeztetve magukat a veszteségükre és a velük szemben elkövetett igazságtalanságokra. Fontosak lehetnek még azok a kiscsoportok is, amelyek megfogalmazott célja a trauma hordozása, az emlékek fenntartása (Degloma, 2009).

Természetesen ezen a ponton joggal merülhet fel az olvasóban, hogy miért is ragaszkodnak csoportok ennyire erôsen az áldozattá válásuk emlékeihez? Az áldozatokról hagyományosan azt gondoljuk, hogy alacsony státuszúak, gyengék és kiszolgáltatottak, mégis úgy tûnik, hogy a csoportok akár még versengenek is egymással, hogy betölthessék ezt a szerepet (Noor és mtsai, 2012; Sullivan és mtsai, 2012). A traumatikus, szélsôséges eseményekrôl fenntartott reprezentációk egyik elônye, hogy azok az ellenállás epizódjait is hordozzák (Vollhardt, 2009a): olyan hôsöket és hôsies eseményeket, amelyekból a csoport tagjai pozitív identitást meríthetnek (Bilewicz és Jaworska, 2013). Ugyanakkor bizonyos körülmények között más okai is lehetnek annak, hogy egy csoportnak érdekében álljon az áldozati szereppel való hosszasabb azonosulás.

A tanulmány harmadik részében bemutatjuk azokat az okokat, amelyeket a szociálpszichológia funkciónak nevez. A funkciók mellett kitérünk az észlelt kollektív áldozatiság tüneteire és következményeire is, bár sokszor ennek a három tényezônek a külön említése inkább didaktikus okokból történik, és a valódi életben a funkciók, tünetek és következmények elválaszthatatlanul összefonódnak egymással.

\section{AZ ÉSZLELT KOLLEKTÍV ÁLDOZATI IDENTITÁS FUNKCIÓI, TÜNETEI ÉS KÖVETKEZMÉNYEI}

\section{Az észlelt kollektív áldozati identitás funkciói}

Az észlelt kollektív áldozati identitásnak a csoport életében betöltött funkciói adhatnak magyarázatot arra, hogy miért éri meg egy csoportnak áldozati identitást felvennie, fenntartania. Bar-Tal és munkatársai (2009) részletesen összegyújtötték azokat a tényezóket, amelyek hozzájárulnak ahhoz, hogy az áldozati identitás kialakítása és fenntartása adaptív és funkcionális legyen a csoport számára. A következôkben bemutatjuk ezeket a funkciókat, kiegészítve az észlelt kollektív áldozatisággal kapcsolatos újabb kutatások eredményeivel.

A kollektív áldozati identitás magjában lévô áldozati hiedelmek (az áldozattá válás kontrollálhatatlanságát, igazságtalanságát, erkölcstelenségét, a másik csoport fe- 
lelôsségét hangsúlyozó vélekedések) egyik legfontosabb funkciója, hogy magyarázattal szolgálnak a csoportok közötti konfliktus természetével kapcsolatban. Kijelölik a felelősöket és segítenek eligazodni abban, hogy ki a „jó” és ki a „rossz”. A tét óriási: mivel az áldozat-agresszor pozíciók sokszor dichotóm, nem felosztható szerepeknek tûnnek, így az a csoport, amelyik nem képes magát áldozatként bemutatni, könnyen az agresszor szerepébe kerülhet (Noor, Brown, Gonzalez, Manzi és Lewis, 2008; Noor, Brown és Prentice, 2008). Amikor a csoport magára áldozatként, a külsố csoportra agresszorként tekint, az végsố soron még inkább kiélezi a csoportok közötti különbségeket. A kollektív áldozati identitás ennek segítségével különböztet meg, és vezet a felsôbbrendûség érzéséhez: az áldozat minden esetben a pozitív morális szereplôje a történteknek (Vollhardt, 2009a). Megerôsödik az az érzés, hogy a saját csoport céljai a helyes célok, egyúttal megtörténik a másik csoport céljainak delegitimizálása (Bar-Tal és mtsai, 2009).

Azzal, hogy a magyarázat révén értelmet adnak a csoporttal történt eseményeknek, a kollektív áldozati hiedelmek csökkentik a stresszt és a szorongást is (Bar-Tal és mtsai, 2009; Janoff-Bulman, 1992; Updegraff, Silver és Holman, 2008). Morális igazolásként és felmentésként múködnek a saját csoport agressziójával kapcsolatban: mivel a másik csoport a hibás, így a saját csoport által elkövetett destrukció legitimnek tûnik, és pusztán az önvédelem igénye motiválja (Ignatieff, 1993; Maoz és Eidelson, 2007; Noor, Brown, Gonzalez, Manzi és Lewis, 2008; Wohl és Branscombe, 2008). A kollektív áldozati identitást felvevô csoport tagjainak nem kell átélniük a kollektív búntudatot és hasonló, a saját csoportra nézve kritikus érzelmeket, hiszen ezek előfeltétele a saját csoport felelốsségének elfogadása lenne (Vollhardt, 2012). Wohl és Branscombe (2008) vizsgálatában például kanadai zsidó vizsgálati személyek, miután egy holokausztról szóló cikket olvastak el (emlékeztetô az áldozattá válásra), kevesebb búntudatot éltek át az izraeli hadsereg palesztinok ellen a jelenben elkövetett túlkapásaival kapcsolatban. A két vizsgálati csoport - az emlékeztetốt olvasó vs. nem olvasó - reakciói között a fó különbség abban volt, hogy az emlékeztetôt olvasó vizsgálati személyek sokkal inkább vélték úgy, hogy az izraeli hadsereg lépései legitim reakciók voltak a palesztinok által korábban elkövetett terrorcselekményekre. Ugyanezt a hatást sikerült kimutatni amerikai vizsgálati személyek esetében is: a Pearl Harborra vagy 9/11-re emlékeztetett amerikai vizsgálati személyek legitim reakcióként élték meg, és kevesebb búntudatot mutattak az amerikai hadsereg Irakban elkövetett túlkapásaival kapcsolatban, mint az emlékeztetôt nem olvasó vizsgálati személyek. A Wohl és Branscombe által elvégzett vizsgálat egyik fontos eredménye volt, hogy a saját csoport felmentése és a külsố csoport hibáztatása akkor is megnôtt, ha az emlékeztetô az áldozattá válásra semmilyen módon nem volt kapcsolható a jelenlegi eseményhez: Pearl Harbor (a japánok által az amerikaiak ellen elkövetett agresszió) ugyanúgy felmentố hatással járt, mint az iraki háborúval közvetlenebb kapcsolatba hozható 2001. szeptember 11-én elkövetett terrorcselekmények.

A saját csoport által elkövetett agresszióval kapcsolatos morális feljogosultság jelentôségét és csoportközi kapcsolatokra kifejtett hatását mutatta ki Klar, Schori-Eyal és Klar (2013) is vizsgálatukban. Kutatásuk kiindulópontjául az a megközelítés szolgál, amely szerint a holokausztnak négy eltérô „hangja” vagy üzenete fogalmazható meg a zsidó nép számára: „Soha ne légy passzív áldozat”, „Soha ne hagyd cserben társai- 
dat”, „Soha ne legyél passzív megfigyelôje az eseményeknek”, és „Soha ne legyél elkövetô”. Ugyanazon történelmi eseményből származtatott eltérô tanulságok más-más kimenetelhez vezetnek a jelenlegi csoportközi kapcsolatok terén. A holokauszt négy üzenete közül az elsô, vagyis a „Soha ne légy passzív áldozat” tartalma az Áldozati Orientáció (Perpetual Ingroup Victimhood Orientation Scale, PIVO; Schori-Eyal, Klar és Roccas, 2009) skálájával vált operacionalizálhatóvá. Ennek lényege az a vélekedés, hogy a saját csoport folyamatos üldöztetéseknek van kitéve különböző ellenségek által; a magas értéket eléróket erôs bizalmatlanság jellemzi, hajlamosak több ellenséges szándékot tulajdonítani a külsố csoportok tagjainak (Schori-Eyal, 2011), valamint azt vallják, hogy a csoport traumája egyedi. Ezzel szemben a másik véglet: a „Soha ne légy elkövetô" üzenetének tartalmát mérhetôvé tevő skála (Agresszorrá Válás Félelme Skála, Fear of Victimizing Scale, FOV) az amiatti félelmet igyekszik megragadni és mérhetôvé tenni, hogy a múltbeli áldozattá válásból kifolyólag a csoport elveszítheti morális érzékenységét ellenségei helyzete iránt, vagyis az a veszély fenyegeti a csoportot, hogy végül ugyanúgy bánnak más emberekkel, ahogyan velük bántak ellenségeik. Az eredmények szerint, míg az Áldozati Orientáció Skála pozitív, az Agresszorrá Válás Félelme Skála negatív kapcsolatot mutatott a morális feljogosultság érzésével, azzal a vélekedéssel, hogy egy csoport megtehet bármit saját önvédelme érdekében, még erkölcsi szempontból megkérdôjelezhetô cselekedeteket is. A morális feljogosultság aztán negatívan kapcsolódott a csoportalapú búntudat átéléséhez, pozitívan pedig az olyan amorális döntéshozatali folyamatokhoz, melyek például a külsố csoport civil lakosságának sérülését eredményezô cselekedetek támogatását jelentik. Mindez azt jelenti, hogy míg a holokauszt „Soha ne legyél passzív áldozat” üzenetét követôk (az áldozati orientáció skáláján magas pontszámot elérôk) erkölcsileg inkább feljogosítva érzik magukat a más csoportokkal szembeni agresszív fellépésre, nagyobb mértékben támogatják ezeket a cselekedeteket, miközben a kollektív búntudat érzését elutasítják, addig a „Soha ne légy elkövetô” hangot meghallókra ennek éppen ellenkezôje igaz.

Amellett, hogy a morális feljogosultság érzésével a magát áldozatnak tekintô csoport távol tarthatja magát a külvilág kritikájától, további célja lehet a nemzetközi támogatás megszerzése: az elszenvedett sérelmek miatt egyebek között igényt tarthat a nemzetközi közvélemény szimpátiájára, törôdésére, anyagi és politikai támogatására is (Simon és Klandermans, 2001).

A kollektív áldozati tudat elôre ráhangol az esetleges jövoobeli erôszakra és a rossz életkörülményekre. Ez föleg pszichésen fontos: a csoport tagjai képesek felkészülni az elhúzódó konfliktusra, és immunissá válnak a negatív élményekkel szemben. A közösséget nem érheti meglepetés, hiszen készen állnak a legrosszabbra. Az áldozati identitás által implikált folyamatos fenyegetettség érzése növeli a csoport tagjai közötti összetartást: az a tény, hogy közösen vagyunk áldozatok, egységet és szolidaritást teremt, hiszen amellett, hogy az élményeink hasonlóak, a túlélésben is csak egymásra számíthatunk. Ilyen értelemben a jelenbéli fenyegetés és a múlt választott traumái összetartják a csoportot, amolyan társas ragasztóként múködnek, amely megnöveli a kohéziót és összeköti a csoport tagjait (Ignatieff, 1993; Noor, Brown és Prentice, 2008; Ramanathaplillai, 2006; Stern, 1995; Wohl, Branscombe és Reysen, 2010).

A csoporton belüli szolidaritás erôsödésével nô a csoporttal való azonosulás (Jetten, Branscombe, Schmitt és Spears, 2001; Schmitt és Branscombe, 2002), a mobilizá- 
ció és kollektív cselekvés is: például Srí Lankán a történelmi áldozattá válásról szóló narratívákat használták fel a militáns csoportok, hogy újoncokat toborozzanak a tamil emberek közül, és hogy rávegyék óket arra, hogy erôszakos cselekvésekben vegyenek részt (Bar-Tal és mtsai, 2009). De ugyanígy, Menachem Begin, izraeli miniszterelnök 1982-ben a híres megsemmisítô tábor, Treblinka említésével aktiválta az áldozati hiedelmeket, ezzel mobilizálva a csoport tagjait: „Itt Izraelben, a végzetünk az, hogy harcolunk... nem akarunk még egy Treblinkát”, mondta, amikor a Libanon elleni invázió mellett érvelt (Lang, 1996). Itt kell említést tennünk Slobodan Milošević, korábbi szerb és jugoszláv elnökrôl is, akinek az 1389-ben a törökökkel szemben elvesztett koszovói csata után mintegy 600 évvel sikerült egyfajta speciális jelentéssel - sốt jelentôséggel - felruházva a múlt eseményeit, egyesíteni és mozgósítani szerbek tömegeit, és egyben felélesztenie a revans vágyát - a törököket a jelenben szimbolizáló - boszniai muszlimokkal szemben (Bar-Tal és Cehajic-Clancy, 2014; Volkan, 2001). Ezek a példák jól szemléltetik, miként lehet egy csoport korábbi traumáját felhasználva ma élô tagjait erôszakos cselekedetekre sarkallni, történjen ez akár az elszenvedett sérelmek megbosszulására, akár a várható megpróbáltatások megelózése céljából. A csoport addig nyugvó állapotban lévô választott traumájának reaktiválása ritualizált történelmi megemlékezésekkel, vagyis a csoporttraumán való osztozás élményeinek felhasználásával elôsegíti a csoporttagok egymáshoz kapcsolódását, a nemzeti büszkeség erôsödését, a társadalom mobilizálását. Ilyen formában a csoport áldozattá válására való emlékeztetés egyfajta manipulatív eszköznek is tekinthetô a társadalom szélesebb rétegeinek különbözố etnopolitikai célok érdekében történô mozgósítására (Bar-Tal és mtsai, 2009).

2. táblázat. Az észlelt kollektív áldozati identitás funkciói

- Magyarázat, értelemadás, közös valóság megteremtése
- Stressz és szorongás csökkentése
- Felkészít az esetleges jövôbeli erőszakra és rossz életkörülményekre
- Erkölcsi igazolás és felmentés a csoport agresszív tetteivel kapcsolatban
- Szolidaritás és csoportkohézió növelése
- A csoporttal való azonosulás növelése
- Mobilizálás, politikai propaganda
- Nemzetközi támogatás elnyerése

A fentiekben bemutatásra került funkciók - melyeket a 2. táblázatban gyújtöttünk össze - jól mutatják, hogy miért érheti meg bizonyos csoportok számára, hogy átmenetileg vagy tartósan kollektív áldozati identitást alakítsanak ki. Fontos kérdés azonban, hogy milyen következményekkel jár az ilyen módon konstruált identitás a csoporton belüli és csoportközi viszonyokra, valamint tágabban a világgal kapcsolatos nézetekre? A következố részben azt tekintjük át, hogy ha egy csoport esetében kialakul az áldozati identitás, akkor annak milyen jellemzôi lehetnek tünetek és következmények szintjén - melyek lényegében szoros kölcsönhatásban vannak egymással. 


\section{Az észlelt kollektív áldozati identitás destruktív irányba ható jellegzetességei}

Az észlelt kollektív áldozati identitással együtt járó jellegzetességeket - tüneteket és következményeket - kognitív, affektív és viselkedéses dimenziókba szervezve tárgyaljuk.

\section{Az áldozati identitás kognitív jellegzetességei}

Az észlelt kollektív áldozati identitás felvétele már elemi szinten befolyásolja a kognitív folyamatokat: szelektív és torzult információfelvételhez vezet. Bar-Tal és munkatársai (2009; Bar-Tal és Antebi, 1992a; 1992b) úgy vélik, hogy azok a csoportok, amelyek kollektív emlékezetében elsôsorban áldozattá válásukon van a hangsúly, jelenlegi helyzetüket is hajlamosabbak úgy értelmezni - sốt akár torzítani is -, mint amely vélekedéseiket megerôsítô információkat tartalmaz. Másképpen fogalmazva, ezek a társadalmak sokkal érzékenyebben reagálnak azokra a jelekre, amelyek alkalmasak arra, hogy alátámasszák áldozati vélekedéseiket. Ezzel szemben figyelmen kívül hagyják azokat az információkat, amelyek nem illeszkednek elôzetes elvárásaik körébe. A csoport narratívája lényegében kognitív szúrôként funkcionál, és mint ilyen, hatással van az új információk befogadására, feldolgozására, sốt a csoportot érintô döntéshozatalra is. A csoport figyelmi küszöbe a fenyegetést tartalmazó ingerek iránt lecsökken, a csoporttagok ráhangolódnak azokra az információkra, amelyek negatív szándékokat jeleznek: a korábbi eseményekbôl adódó áldozati sémájukat jelenlegi helyzetük értelmezésére használják, és hajlamosak viszonylag ártalmatlan szituációkat is negatív keretben értelmezni, valamint érzékenyebbek lesznek a - vélt vagy valós - provokációra. Halperin és Bar-Tal (2011) reprezentatív izraeli zsidó mintán végzett vizsgálatából az is kiderült, hogy az észlelt áldozatiság az információktól való elzárkózáshoz vezet: azok a vizsgálati személyek, akik az izraeli-palesztin konfliktus áldozatainak az izraelieket látták, kevésbé voltak nyitottak arra, hogy új információkat kapjanak a konfliktusról.

A kollektív áldozati identitás felvétele alapvetôen meghatározza a világról és a konfliktusról alkotott elképzeléseket is. A világ veszélyes hellyé változik, általában nô a sérülékenység érzése, a csoport másoktól való függôségének érzete, és csökken az igazságos világba vetett hit (Bar-Tal és mtsai, 2009). Fasel és Spini (2010) például négy jugoszláv utódállamot (Bosznia-Hercegovina, Horvátország, Macedónia és Szlovénia) vizsgálva és egymással összehasonlítva, azt találta, hogy az áldozattá válás tapasztalata negatív hatással volt az igazságos világba vetett hit egyéni szintjeire a gazdaságilag kevésbé fejlett országokban, Macedóniában és Bosznia-Hercegovinában. Elcheroth (2006) több, konfliktussal kapcsolatban végzett vizsgálata arra is rámutatott, hogy a fizikai erôszakot átélt csoportok tagjainak hite a humanitárius normákban is megrendül.

A világban való eligazodást szolgálja az a kategoriális felosztás, melyben ellenséges és támogató csoportok kerülnek megkülönböztetésre. Ez lényegében megkönnyíti a tájékozódást, és segíti a csoportközi viszonyulások rendszerezését. Az eredeti agreszszoron kívül mindazokkal a csoportokkal (például olyan nemzetközi szervezetekkel, mint az Európai Unió, az Egyesült Nemzetek Szervezete), amelyek nem fogadják el a csoport áldozati státuszát, a magát áldozatnak tartó csoport negatív viszonyulást alakít ki. Ehhez képest, akik empatizálnak vele és segítik a törekvéseit, pozitív színezetet kapnak. Erre jó példa Danielidou és Horvath (2006) vizsgálata, amelyben a ciprusi 
konfliktus kontextusában a török ciprióták észlelt agresszor státusza negatív attitúdöket alakított ki a görög cipriótákban a törökökkel szemben is.

\section{Az áldozati identitás affektív jellegzetességei}

Az áldozati identitásmintázat jellegzetes érzelmi repertoárja jellemzốn a csoport sérülékenységébôl és fenyegetettségéből fakadó, fizikai vagy szimbolikus megsemmisüléstôl való félelem (Halperin, Bar-Tal, Nets-Zehngut és Drori, 2008; Pettigrew, 2003; Schori, Klar és Roccas, 2009), a depresszív érzelmek (pl. önsajnálat), a szégyen és megalázottság érzése (Rice és Benson, 2005; Volkan, 2001), valamint az ellenséges érzelmek (pl. düh, harag; Manzi és González, 2007; Pennekamp és mtsai, 2007) köré épül. Ezek mellett, az áldozatokra jellemzó saját csoport fókusz és egocentrizmus a más csoportokkal szembeni empátia hiányához is vezet (Mack, 1990). Mindehhez a világban lévô más csoportokkal szembeni általános bizalmatlanság is kapcsolódik.

A csoporttal történt korábbi események, illetve az esetlegesen visszatéró élmények szenzitívebbé teszik a csoportot bizonyos érzelmekre. László és Fülöp (2011) magyar történelmi pályaérzelmekkel kapcsolatos kutatásában a vizsgálati személyek a magyar történelem jelentôs csoportközi konfliktusairól kaptak nyolc rövid történetet, melyek felében a magyarok elkövetôk, másik felében áldozatok voltak. Majd azt kellett eldönteniük, hogy egyrészrôl ôk személy szerint, másrészrôl a magyar csoport az adott történelmi helyzetben milyen érzelmeket élnek/élhettek át. Eredményeik szerint azon túl, hogy az események kapcsán jelenben átélt saját és a magyar csoportnak tulajdonított múltbeli érzelmek szoros összefüggést mutattak egymással - elkövetô és áldozat szerepben is az ellenséges, valamint az elkeseredettséget kifejezó negatív érzelmek voltak túlsúlyban, ehhez képest a felelôsségvállalással és a feldolgozottsággal kapcsolatba hozható önkritikus érzelmek az elóbbiekhez képest ritkábban jelentek meg. Ezek alapján, adott szerepben inadekvátnak tûnó csoportalapú érzelmek megjelenése - például a csalódottság és a szomorúság érzéseinek magas gyakorisága elkövetô szerepben, vagy büszkeség átélése áldozatként - azt mutatja, hogy a csoportra jellemzô érzelmi irány a szituatív tényezôktôl független. Ezek az eredmények érthetôvé és értelmezhetôvé válnak akkor, ha számításba vesszük, hogy a magyarok múködésmódjának feltehetốen integratív eleme az áldozati szerep érzelmi dinamikája, amely alapvetôen befolyásolja a csoportszintú érzelmi reakciók megjelenését. Ráadásul a társadalom érzelmi orientációja (Bar-Tal, 2001), vagyis arra való fokozott hajlama, hogy bizonyos érzelmeket kollektív szinten is gyakrabban mutasson, képes arra, hogy ráhangolja a csoport tagjait a társas szituációk bizonyos jelzéseire. Nem csupán arról van szó tehát, hogy bizonyos történelmi események hajlamosítanak bizonyos érzelmek kollektív szinten való fokozott megjelenésére, hanem arról is, hogy a csoport így kialakuló érzelmi orientációja a továbbiakban befolyással van az új helyzetek kiértékelésére is. Bar-Tal arra hívja fel a figyelmet, hogy egy társadalom elsôsorban félelemre épülô érzelmi orientációja, bár bizonyos esetekben adaptív viselkedéses választ eredményez, általánosságban véve azonban bizalmatlansághoz, az ellenség delegitimizálásához vezethet, ami hosszú távon komoly akadályokat állít a csoportközi megbékélés felé vezetô úton. Ezt kiküszöbölendố Bar-Tal szerint hasznosabb lenne a fenyegetô élményekkel teli múltra és jelenre összpontosító félelem helyett a pozitív jövô képét elôtérbe állító 
„remény kultúráját” felépíteni és erôsíteni. Hiszen míg előbbi egy automatikus reflexszerú reakció, ami a vélekedések megszilárdulásához vezet, utóbbi magasabb szintû kognitív aktivitást feltételez, és egyfajta kreativitást és rugalmasságot kíván meg. Nehézséget jelent ugyanakkor, hogy egy félelemhez adaptálódott társadalom számára a jövô bizonytalan és kockázatos; számukra a reményteli béketeremtés egy újfajta élmény, amely új megoldásokat, másfajta hozzáállást kíván.

\section{A kollektív áldozati identitás viselkedéses jellemzôi}

A kollektív áldozati identitáshoz egyrészrôl a tehetetlenség érzése, a kontroll hiánya kapcsolódik; olybá tûnik, hogy a csoport tagjai keveset tudnak tenni a szituáció megváltoztatása érdekében, leginkább passzív elszenvedôi az eseményeknek. Másrészrôl azonban a csoportközi kapcsolatok szempontjából kifejezetten destruktív reakciók jelenhetnek meg. Noor és munkatársai (Noor, Brown, Gonzalez, Manzi és Lewis, 2008; Noor, Brown és Prentice, 2008) versengô áldozatisággal kapcsolatos vizsgálatai például arra mutattak rá, hogy a magát inkább áldozatnak vélő csoport tagjai kevésbé hajlottak a megbocsátásra. Ennél súlyosabb kimenetellel járnak azok a viselkedéses megnyilvánulások, amelyek célja a revans vagy a védekezés: az áldozat csoport tagjai úgy érzik, hogy morális joguk van a bosszúálláshoz, vagy akár olyan „megelôzô” csapások végrehajtásához, amelyek a csoport biztonságát garantálják. A revans vágya és az ehhez kapcsolódó felhatalmazottság érzése az erôszak egyre súlyosbodó spirális körforgásához, az úgynevezett áldozat-agresszor körforgáshoz vezet, amelyben a korábbi áldozatból agresszor lesz (Bar-Tal, 2003; Maoz és Bar-On, 2002; Staub, 1998). A revans vágya gyakran nyilvánul meg az úgynevezett behelyettesító megtorlás jelenségében, az elkövetô csoport azon tagjait megcélozva, akiknek személyesen semmilyen szerepük nem volt az eseményekben (Lickel, Miller, Stenstrom, Denson és Schmader, 2006). Vollhardt (2012) Wohl és Branscombe 2008-ban publikált kutatására hivatkozva a behelyettesítô megtorlást kiegészíti még az áthelyezett agresszió jelenségével: ilyenkor az áldozattá vált csoport olyan csoport tagjaival szemben követ el - számára jogosnak tûnố agressziót -, amely nem vett részt a saját csoport ellen elkövetett agresszióban (pl. a japánok agressziója az amerikaiak ellen indokolttá teszi az irakiakkal szembeni agressziót). A revans vágya a katonai fellépés támogatásához vezet: Maoz és Eidelson (2007) izraeli reprezentatív mintán végzett vizsgálatából az derült ki, hogy azok a vizsgálati személyek, akik általában úgy gondolták, hogy a saját csoport sérülékeny, és hogy más csoportok igazságtalanul jártak el vele szemben, jobban támogatták az olyan szélsôséges konfliktuskezelési stratégiákat, mint például a palesztinok bombázása és/ vagy kitelepítése a környezó arab országokba.

Mindezek együtt - áldozati hiedelmek, negatív csoport alapú érzelmek, destruktív viselkedések - rajzolják ki az áldozati identitást felvevô csoport képét, melyeket a 3. táblázatban összegeztünk.

Az eddig bemutatott vizsgálatokat látva a következô konklúzióra juthatunk: a saját csoport áldozatként való megélése - miközben kétségtelenül fontos funkciókat tölt be a csoport életében - többnyire negatív következményekhez vezet, amelyek súlyosan károsíthatják a csoportközi viszonyokat. 
3. táblázat. Az észlelt kollektív áldozati identitás kognitív, emocionális és viselkedéses szinten megnyilvánuló destruktív tünetei és következményei

\begin{tabular}{|c|c|c|}
\hline \multirow[b]{2}{*}{$\begin{array}{l}\text { Kognitív } \\
\text { jellemzók }\end{array}$} & Kognitív torzítások & $\begin{array}{l}\text { - Szelektív és torzult információfelvétel } \\
\text { - Fokozott érzékenység a fenyegetố ingerek } \\
\text { irányába } \\
\text { - Új információval szembeni ellenállás }\end{array}$ \\
\hline & $\begin{array}{l}\text { Hiedelmek/Vélekedések a } \\
\text { világról, a saját csoportról } \\
\text { és a másik csoportról }\end{array}$ & $\begin{array}{l}\text { - A világ veszélyes } \\
\text { - Csökken az igazságos világba vetett hit } \\
\text { - Megrendül a humanitárius normákba vetett } \\
\text { hit } \\
\text { - Más csoportok ártani akarnak } \\
\text { - A másik csoport céljai delegitimek } \\
\text { - A felelôsség a másik csoporté } \\
\text { - A saját csoport kiszolgáltatott } \\
\end{array}$ \\
\hline \multicolumn{2}{|c|}{ Érzelmi jellemzôk } & $\begin{array}{l}\text { - Depresszív érzelmi dinamika } \\
\text { - Tipikus érzelmek: } \\
\text { - Félelem, önsajnálat, megalázottság, szégyen } \\
\text { - Harag, gyúlölet } \\
\text { - Bizalmatlanság } \\
\text { - Empátia hiánya más áldozatokkal szemben } \\
\text { - A saját csoportra nézve kritikus érzelmek } \\
\text { (pl. kollektív búntudat) elhárítása } \\
\end{array}$ \\
\hline \multicolumn{2}{|c|}{ Viselkedéses jellemzôk } & $\begin{array}{l}\text { - Agresszió } \\
\text { - Revans } \\
\text { - „Megelóző” csapások } \\
\text { - Behelyettesítô megtorlás } \\
\text { - Áthelyezett agresszió } \\
\text { - Megbocsátásra való képtelenség }\end{array}$ \\
\hline
\end{tabular}

Az észlelt kollektív áldozati identitás konstruktív irányba ható jellegzetességei

A fentebb felsorolt negatív következmények mellett az elmúlt években felerôsödött az a kutatási vonal, amely a kollektív áldozattá válás pozitív következményeit tanulmányozza. Az egyik nyilvánvaló pozitív következmény a csoporton belül áll elô: az áldozattá vált csoporttagok fokozott támogatása, a velük szemben megnyilvánuló proszociális viselkedés növekedése figyelhetố meg (Dumont, Yzerbyt, Wigboldus és Gordijn, 2003; Wayment, 2004). Száz holokauszttúlélôvel folytatott vizsgálat során a résztvevôk 82\%-a számolt be arról, hogy a koncentrációs táborokban igyekezett segítséget nyújtani rabtársainak, akár étele és ruházata megosztásával, akár érzelmi támasz nyújtásával (Kahana, Kahana, Harel és Segal, 1985). Egy, az 1990-es évek elején megkezdett, Horvátországban lefolytatott longitudinális vizsgálatban pedig azt kapták, hogy a háború intenzívebb légicsapásokkal járó idôszakát követôen 5-6 éves gyerekek - tanáraik megítélése alapján - több proszociális viselkedést (pl. az édességek és játékok megosztása a többiekkel, vagy a rászoruló gyerekek iránti sajnálat kifejezése) mutattak társaik iránt, mint a háborút megelőzően; miközben az agresszív cselekedeteik mértéke nem változott számottevôen (Raboteg-Saric, Zuzul és Kerestes, 1994).

Staub és Vollhardt (Staub, 2003, 2005; Staub és Vollhardt, 2008; Vollhardt, 2009a, 2009b; Vollhardt és Staub, 2011) nevéhez köthetô a „szenvedésból született altruiz- 
4. táblázat. Az észlelt kollektív áldozati identitás kognitív, emocionális és viselkedéses szinten megnyilvánuló konstruktív tünetei és következményei

\begin{tabular}{|c|c|}
\hline Kognitív jellemzôk & $\begin{array}{l}\text { - Észlelt hasonlóság } \\
\text { - Perspektívafelvétel } \\
\text { - Újrakategorizálás (fölérendelt kategória létrehozása) }\end{array}$ \\
\hline Érzelmi jellemzôk & - Bizonyos esetekben empátia \\
\hline $\begin{array}{l}\text { Viselkedéses jellem- } \\
\text { zốk }\end{array}$ & $\begin{array}{l}\text { - Saját csoporton belüli és csoportok közötti proszociális viselkedés } \\
\text { - Az áldozatok támogatása, segítése } \\
\text { - „Szenvedésbôl született altruizmus” } \\
\text { - Áldozati csoportok közötti szövetségek }\end{array}$ \\
\hline
\end{tabular}

mus” hipotézise. Ennek lényege, hogy különbözó szenvedéseknek kitett emberek nem traumatizált társaikhoz képest nagyobb hajlandóságot mutatnak arra, hogy más áldozatokon segítsenek, nemcsak csoporton belül, de csoportok között is. Az áldozattá válás tapasztalatában való közös osztozás, az élmények hasonlóságának észlelése egyszersmind felülírhatja és átjárhatóvá teheti a csoportok közötti határokat, és egy új, fölérendelt kategória, amolyan közös áldozati identitás jön létre, mely megnöveli a külsố csoportok felé irányuló proszociális tendenciák megjelenését is. Eszerint az áldozati tudat konstruálásának létezik egy olyan módja, amely az áldozattá válás élményébôl éppen egyfajta morális felelôsséghez vezet: az áldozattá vált csoport tagjai küldetésüknek érzik, hogy mások szenvedéseit megakadályozzák (Lifton, 1967; illetve lásd fentebb a holokauszt „hangjai”: „Soha ne hagyd cserben társaidat”, „Soha ne legyél passzív megfigyelője az eseményeknek; Klar, Schori-Eyal és Klar, 2013). A „szenvedésból született altruizmus" hipotézisét mind történelmi példák, mind empirikus bizonyítékok alátámasztják. Történelmi példái azok a tiltakozások, amelyeket a holokausztot átélt zsidó nép tagjai tettek a másokkal szembeni erószak ellen a „soha többé” mottóját használva. Ilyen például a holokauszttúlélók tiltakozása My Lai ellen, a jugoszláv háború során a muszlimokat és a keresztényeket egyaránt segítô lépéseik, és a zsidó szervezetek erôfeszítései, hogy megállítsák a darfuri népirtást (Lifton, 2003; Serotta, 1994). Több empirikus vizsgálatot is végeztek a témában: Vollhardt és Staub (2011) eredményei szerint valóban létezik proszociális attitúd a korábbi áldozatok részérôl az újonnan áldozatokká váló külsô csoporttagok irányába, fơleg akkor, ha az áldozattá válás kontextusa hasonló. Ezt a proszociális attitûdöt a vizsgálati személyek részérôl átélt empátia közvetítette, azaz a saját áldozati élmény és a másik áldozati élménye közötti kapcsolatot a másik helyzetébe való fokozott beleélés hozta létre.

Ha kognitív, affektív és viselkedéses dimenziók mentén szeretnénk összefoglalni a következmények konstruktív irányba mutató jellemzôit, akkor az eddig rendelkezésre álló eredmények alapján a következô megállapítást tehetjük: az áldozattá válás tapasztalata kognitív szinten az élmények észlelt hasonlósága, valamint a perspektívafelvétel révén az áldozatok közös fölérendelt kategóriáját hozza létre. Ez érzelmi szempontból az empátia megjelenéséhez, végsố soron pedig proszociális viselkedésekhez vezet. Mindezeket a 4. táblázatban foglaltuk össze.

Láthattuk, hogy az áldozati élmények bizonyos esetekben destruktív, más esetekben konstruktív kimenetelekhez vezetnek. Vajon mi okozhatja, hogy az áldozattá válás 
szubjektív tapasztalatából egyszer a morális feljogosultság, máskor a morális felelôsség érzése emelkedik ki? A következô részben az áldozati élmények eltérô megkonstruálási módjaival és ezek csoportközi kapcsolatokra való hatásával foglalkozunk.

\section{A KOLLEKTÍV ÁLDOZATTÁ VÁLÁS TAPASZTALATÁNAK KÜLÖNBÖZŐ ÉLMÉNYSZERVEZŌDÉSI MÓDJAI}

\section{Exkluzív versus inkluzív áldozati vélekedések}

Vollhardt (2012) szerint az áldozati élmények két alapvetố dimenzió mentén különböznek egymástól: egyrészt, hogy milyen keretben értelmezôdnek az események - egy specifikus konfliktus keretében vagy globális keretben -, másrészt, hogy milyen széles a fókuszuk - a hangsúly kizárólag a saját csoport szenvedésein van, vagy figyelembe veszi a hasonlóságokat más csoportok áldozattá válásával kapcsolatban is. Az elsô dimenziót Vollhardt (2012) globális versus specifikus áldozati hiedelmeknek nevezi, a második dimenziót pedig exkluzív versus inkluzív áldozati hiedelmeknek. A két dimenzió négy lehetséges esetet rajzol ki. A globális exkluzív áldozati hiedelmeket valló csoport tagjai az áldozati szerep kizárólagosságát hangsúlyozzák, a saját csoport traumáinak egyediségét és disztinktivitását emelik ki. Úgy érzik, hogy ami velük történt, az egyedülálló az emberiség történetében: szenvedésük jellege és/vagy mértéke nem hasonlítható semmilyen más szenvedéshez. A globális inkluzív áldozati hiedelmeket valló csoport tagjai tudomásul veszik, hogy a világtörténelem során voltak más olyan csoportok, amelyeknek a szenvedése összevethetố a saját csoportjuk szenvedésével. A specifikus exkluzív áldozati hiedelmek azt takarják, amikor egy csoport tagjai úgy gondolják, hogy egy adott konfliktus kizárólagos áldozatai ôk, szemben a konfliktusban részt vevô többi csoporttal (errôl részletesebben írtunk korábban versengó áldozatiság néven). A specifikus inkluzív áldozati hiedelmeket valló csoport tagjai elismerik, hogy az adott konfliktusnak voltak más áldozatai is rajtuk kívül - akár épp a szembenálló csoport is. Ez a saját és másik csoport szenvedéseinek kölcsönös elismerését, az átélt élmények közötti hasonlóságot hangsúlyozó vélekedéseket foglal magában.

Ahogy Vollhardt (2009a) felhívja rá a figyelmet: a csoportok közötti hasonlóságok észlelése és a fölérendelt, inkluzív kategória létrehozása az események sokkal absztraktabb megkonstruálását (magas szintû́ konstruálás; Trope és Liberman, 2003) követeli meg. Ez a fajta „általánosítás” ugyanakkor veszélyezteti az egyes áldozattá vált csoportok azon igényét, miszerint szenvedéseik minden részletükben és súlyosságukban széleskörúen elismerésre kerüljenek; hiszen ez jelenti számukra az elsô lépést traumájuk feldolgozása, így a gyógyulás felé. Ezzel szemben, bár a specifikus és kontextualizált vonások kihangsúlyozása (alacsony szintú konstruálás, Trope és Liberman, 2003) valóban sokkal nagyobb figyelmet fordít az események részleteire, egyúttal azonban a saját és a másik csoport élményeinek különbségeire is nagyobb hangsúly helyezôdik, megteremtve ezzel a csoportok közötti áldozati versengés egyik előfeltételét. Az igazi kihívás tehát a disztinktivitás egy bizonyos fokának elismerése, anélkül, hogy aprólékos részletekbe vagy a szenvedések összehasonlításába bocsátkoznánk (Noor, Brown, Gonzalez és mtsai, 2008; Noor, Shnabel, Halabi és Nadler, 2012; Volkan, 2001; Vollhardt, 
2009a). A megoldás valahol a kettô között helyezkedik el: az áldozatiság inkluzív reprezentációján túl az egyes csoportok különbözôségeinek - például specifikus történelmi eseményeinek, narratívájának, identitásának - elismerése, a másik csoport státuszának legitimálása is nélkülözhetetlen a csoportközi megbékélés folyamatában. Ebbôl a szempontból - ahogy Bar-Tal és Cehajic-Clancy (2014) felhívják rá a figyelmet - két csoport kapcsolatának javítása elôször is ott kezdôdik, hogy kölcsönösen belátják, a közöttük lévô konfliktusnak legalább két - egymástól teljesen eltérô - olvasata van. Egy új, közös narratíva létrehozása érdekében szükség van arra, hogy a két fél egymás múltját kölcsönösen megismerje, majd közös nevezőre hozza. Ebben a folyamatban a saját csoport kollektív emlékeinek is jelentôs mértékben felülvizsgálatra kell kerülniük, hogy összehangolhatóvá váljanak a másik csoport által átélt élményekkel (Asmal, Asmal és Roberts, 1997; Hayes 1998; Hayner, 1999; Kopstein, 1997; Norval, 1998, 1999; Salomon, 2004).

\section{Az élményszervezés módjának jelentôsége a csoportközi kapcsolatokban}

Az exkluzív versus áldozati hiedelmek csoportközi attitúdökre kifejtett eltérô hatásainak empirikus bizonyítékai is vannak. Vollhardt (2013) kísérleti módszert használó vizsgálatában azok az amerikai zsidó vizsgálati személyek, akiknek a holokausztot inkluzív, univerzális módon mutatták be, több hajlandóságot mutattak, hogy segítsék a darfuri népirtás áldozatait. Vollhardt és Bilali (2015) három afrikai országot érintô vizsgálatában szintén kapcsolatot talált a saját csoport áldozattá válásának inkluzív konstrukciója és a pozitív, proszociális csoportközi attitúdök között, szemben az exkluzív áldozati vélekedésekkel, melyek sokkal inkább negatív külsố csoport iránti attitûdhöz (bizalmatlansághoz és társas távolsághoz) vezettek. Vollhardt, Nair és Tropp (2016) eredményei pedig azt is kimutatták, hogy adott társadalomban kisebbséginek számító csoportok (pl. második generációs vietnami-amerikai bevándorlók; elnyomásban élô indiaiak) inkluzív áldozati vélekedéssel rendelkezô tagjai a menekültek és bevándorlók iránti támogató attitûddel rendelkeztek, mely hatást a kollektív áldozattá válás személyes és családi tapasztalatai is befolyásolták. De az eredmények sorában ide illeszthetô Wohl és Branscombe (2005) korábbi kutatása is. Vizsgálatukban a holokausztot fogalmazták meg két eltérô kategóriaszinten: az egyik verzióban a németek követték el a zsidókkal szemben (társas kategóriák hívása), a másik verzióban pedig az egész emberiség (zsidók és németek közös fölérendelt kategóriája) traumájaként mutatták be az eseményeket. Az emberiség mint fölérendelt kategória beemelése, vagyis az inkluzivitás növelése a csoportközi megbocsátás előmozdításának hatékony eszköze volt.

Mindezek alapján azt mondhatjuk, hogy az áldozati vélekedések inkluzív típusa a külsố csoportok iránti pozitív attitûdöt eredményez. Az inkluzív típusú élményszervezés hosszabb távon az áldozati csoportok közötti szövetségek, bizonyos ügyekben történô összefogás, közös kollektív cselekvések előmozdítója is lehet (Vollhardt, 2015). A következókben azt vesszük szemügyre, hogy mik lehetnek azok a motivációs tényezôk, amelyek a csoportok közötti inkluzivitás felismerését és hangsúlyozását segíthetik elô. 


\section{Az inkluzivitást elósegitô és akadályozó tényezók}

Bizonyos szempontból feltételezhetô volna, hogy két áldozati csoport - hasonló pozíciójából fakadóan - viszonylag könnyen megtalálja egymással a közös hangot, és támogatást nyújt egymásnak. Ezt az elképzelést támasztják alá Warner és Branscombe (2012) eredményei is, melyek szerint a konfliktusban nem részt vevố megfigyelôk úgy gondolják, hogy egy népirtás áldozatai nagyobb hajlandóságot mutatnak, hogy más áldozatokon segítsenek. De ugyanígy a többségi csoport tagjai elvárják a hátrányos helyzetú kisebbségek tagjaitól, hogy toleránsabbak legyenek más kisebbségekkel, mint például a migránsokkal (Fernández, Branscombe, Saguy, Gómez és Morales, 2014). Mintha az áldozatiság élménye „csapdát állítana”, és amolyan morális kötelességként nehezedne a csoportokra, külsô elvárásként megfogalmazva a más áldozati csoportok megóvásának igényét. Ez azonban sokszor épp az ellenkezô hatást válthatja ki a kisebbségi csoportok tagjaiban, akik, még ha a többségi - nem stigmatizált - csoportokkal megegyezó attitúdöket is mutatnak a másik áldozati csoport felé, mégis intoleránsabbnak és immorálisabbnak ítélik óket.

A helyzet tehát korántsem egyszerú: hogy az áldozatiság élményében osztozó csoportok meglelik-e egymásban lehetséges partnerüket és szövetségesüket, az számos tényező függvénye. Az inkluzív áldozati kategóriába való bekerülésre, az áldozattá válás tapasztalatának hasonlóságán túl a kulturális hasonlóság és a területi közelség például növelheti az esélyt. Ugyanakkor az inkluzív áldozati tudat kialakulása szempontjából Vollhardt (2015) szerint például egyáltalán nem mellékes, hogy melyik az a másik áldozati csoport, amelynek a szenvedéseit a saját csoport szenvedéseihez hasonlítjuk. Az inkluzív áldozati vélekedések gyakran szelektívek. Cohrs, McNeill és Vollhardt (2015) északír kontextusban végzett kutatásában az inkluzív áldozati konstrukcióknak univerzális és szelektív típusát különböztetik meg. Míg előbbi nem tesz különbséget az áldozattá válás különbözố élményei között, és elsôsorban az erôszakos konfliktus által okozott emberi szenvedésre helyezi a hangsúlyt, függetlenül annak okaitól, utóbbi szerint más áldozati csoportok kizárólag az élmények hasonlóságának (pl. terrorizmus áldozatai, megszállás áldozatai) függvényében tartozhatnak a közös áldozati kategóriába. Ennek mozgatórugója feltehetôen elsôsorban a saját csoport szenvedéseinek elismertetése: a csoport nem hajlandó bármely egyéb áldozattá vált csoporttal „közösséget vállalni”, ezzel saját sérelmeinek egyediségét eljelentékteleníteni, ehelyett egyfajta szelektivitás jellemzi. Kizárólag olyan áldozati csoporttal kapcsolatban fogalmaz meg inkluzivitást - azaz alkot szövetséget -, amely esetében az élmények hasonlósága - és esetleg a szóban forgó csoport elismertsége - révén hozzásegíti saját csoportját szenvedéseinek szélesebb körú elismertetéséhez. Cohrs és munkatársai eredményei szerint az inkluzív áldozati vélekedéseknek kizárólag az univerzális megközelítése vezetett megbékélésre való hajlandósághoz, míg ennek szelektív típusa inkább a versengó áldozatisággal volt összefüggésbe hozható. Eszerint tehát hiába jelenthetnének elviekben megfelelô alapot egy közösen osztott áldozati identitás létrehozásához a hasonló tapasztalatok, ugyanabban a történelmi eseményben elszenvedett sérelmek, vagy netán ugyanaz az elkövetô csoport, különbség lehet abban, hogy a hasonló módon áldozattá vált csoportok sérelmeit mennyire ismerik el más csoportok. Örmény ame- 
rikaiak például gyakran adnak hangot neheztelésüknek, mely szerint jelentôs eltérés van a holokauszt és az örmény népirtás nemzetközi elismerésében, hangsúlyozva egyúttal azt is, hogy mindez a két csoportot egyértelmúen távolabb sodorja egymástól. De ugyanígy az sem mellékes, hogy ki kommunikálja a csoportok élményei közötti hasonlóságot; sokkal kedvezóbb a reakció, amikor a saját csoport egy tagja fejezi ki a másik csoport tapasztalataival való hasonlóságot, míg kevésbé pozitív csoportközi attitúdöt eredményez, ha a külsô csoport egy tagja beszél róla (Gómez, Dovidio, Gaertner, Fernández és Vazquez, 2013).

Rendszerezve az áldozatiság inkluzív megközelítésének irányába ható tényezóket, Vollhardt (2015) az áldozati csoportok közötti szövetségek létrehozásának háromféle lehetséges motivációját különíti el: a külsố csoportra való fókuszálás, a saját csoportra való fókuszálás, illetve a kölcsönös elônyök szem elốtt tartása. Az elsô szerint a saját csoport elsôdleges célja - a másik csoporttal való inkluzív áldozati reprezentációja során - a külsố csoporton való segítés. Jó példa erre, amikor hátrányos helyzetú kisebbségi csoportok támogatásukat fejezik ki a menekültekkel szemben (Nair és Vollhardt, 2012; Vollhardt, Nair és Tropp, 2016). Persze - hívja fel a figyelmet Vollhardt (2015) - ez még nem zárja ki egyéb, olyan saját csoport fókuszú stratégiai szempontú motivációk meglétét, mint amilyen a saját csoport képének javítása. Ráadásul a rászorulók segítése amolyan megküzdési mechanizmusként is szolgálhat, mint például egy traumát követően helyreállítani a csoport ágenciájának érzését (pl. Hernandez-Wolfe, 2011; Hopkins, Reicher, Harrison, Cassidy, Bull és Levine, 2007; Van Leeuwen és Mashuri, 2013; Vollhardt, 2009b). Mindez azonban már átvezet minket a saját csoport fókuszú motivációkhoz. Eszerint a saját csoport - saját érdekeit szem elôtt tartva - azért hoz létre más csoportokkal inkluzív áldozati kategóriát, hogy ezzel támogatást szerezzen saját ügyének. Az alevitek például saját csoportjuk elnyomását a holokauszttal hozzák kapcsolatba (Yildiz és Verkuyten, 2011). A saját csoport szenvedéseinek egy széles körben elismert történelmi eseményhez való hasonlítása saját traumájuk elismertetésére tett kísérletként is értelmezhetô (Power, 1999). A harmadik lehetséges motiváció az áldozatiság inkluzív megközelítésére, ha mindkét fél számára hasznot hoz. Például a kisebbségi csoportok közötti koalíciók mindkét csoport státuszának javítását, valamint a közös politikai célok elérését is szolgálja.

Mindezek alapján elmondható, hogy a destruktív és a konstruktív csoportközi attitûdök alapjául az áldozati hiedelmek eltérô megkonstruálása szolgál. Míg az áldozati élmények exkluzív jellege - mely a saját csoportra fókuszál, és a saját csoport szenvedéseit egyedinek és kizárólagosnak tartja -, negatív csoportközi következményekhez vezet, addig az áldozati hiedelmek inkluzív jellege - mely a saját csoport szenvedése mellett felismeri és elismeri, hogy más csoportok is hasonló módon szenvedtek a történelmük során - pozitív csoportközi kimenetekhez vezet.

Tanulmányunk negyedik részében bemutatjuk a kollektív áldozatiság kutatásának magyar kontextusát: azaz a hazai szociálpszichológiában hogyan jelenik meg az áldozatiság magyar nemzeti identitást átható dimenziója. 


\section{AZ ÉSZLELT KOLLEKTÍV ÁLDOZATISÁG KUTATÁSA A MAGYAR KONTEXTUSBAN}

A magyar kollektív identitás áldozati jellegével kapcsolatban számos publikáció, tudományos értekezés és elmélkedés született mind a bölcsészettudományok, mind a társadalomtudományok terén. Míg a történetírás bizonyos szempontból a tapasztalatok objektív leírásával, az események közötti összefüggések feltárásával foglalkozik (természetesen már amennyire lehetséges objektív történetírásról beszélni), addig a szociálpszichológiai kutatások inkább az események szubjektív szintú, társadalomlélektani hatásait vizsgálják.

Az alábbiakban igyekszünk ismertetốt nyújtani arról, hogy a szociálpszichológiai kutatásokban hogyan jelenik meg az áldozatiság magyar nemzeti identitást átható dimenziója.

\section{Kollektív áldozatiság a szociálpszichológiai munkákban}

A magyarság jellemzôinek lélektani szempontú leírása visszanyúlik egészen a nemzetkarakterológiák, nemzeti sztereotípiák és autosztereotípiák virágzásának idôszakába (Hunyady, 1997; 2003; 2004; Ladányi, 2015). Bár ezek tárgyalására ehelyütt nincs lehetôség, közülük Koestler (idézi Ladányi, 2015) gondolatmenete azért mindenképpen említésre érdemes. Eszerint a magyar az egyetlen olyan nép Európában, amelynek nincs „faj- és nyelvrokona”, és mint ilyen, a „legmagányosabb a földrészen”, szerinte „magyarnak lenni kollektív neurózis”. Ez a bizonyos „egyedül vagyunk” érzése Csepeli (2013b) érvelése szerint az önsajnálatot és az önfelmentést egyaránt tökéletesen szolgálja, és mint ilyen, egyben önbeteljesítô jóslatként is múködik. Kiemeli azonban, hogy míg például a németeknél ez a fajta etnocentrizmus felsôbbrendûséghez, büszkeséghez és hiúsághoz vezet, addig a magyar identitás eredendố negativizmusa miatt ez sokkal inkább a magára hagyatottság és a kollektív szorongás érzéseinek forrásává válik. Amint Pataki (2011) rámutat, a magyar népre egyszerre jellemző a - magyarok áldozataiért rendszerint „rút hálátlansággal” fizetố Európa miatt érzett - állandó cserbenhagyottság és örök sértettség, valamint az „Európa utáni sóvárgó érzület”. Szerinte ezt a tartós érzelmi mintázatot az „Európa védôbástyája”-képzet táplálja.

Az elmúlt években is számos szociálpszichológiai kutatás és értekezés foglalkozott a magyar nemzeti identitás jellegzetességeinek elemzésével és tárgyalásával (pl. Csepeli, 1992, 2002; Csepeli és Örkény, 1996; Csepeli, Örkény, Székelyi és Poór, 2004; Erôs, 2001; 2007; Hunyady, 1997; 2003; Pataki és Ritoók, 1999). Ezek közül, ami témánk szempontjából mindenképpen megemlítendô, az Csepeli (2013a) gondolatmenete a nemzeti emlékezettel kapcsolatban. Szerinte a magyar társadalom nemzeti emlékezetében két trauma kap központi szerepet: az egyik az I. világháborút lezáró trianoni békeszerzôdés, a másik pedig a II. világháború során a holokauszt. Egy 2010-es országos reprezentatív mintán végzett felmérés szerint a résztvevốk 66\%-a, 2012-ben pedig valamivel több, $68 \%$-a jelölte meg a trianoni békeszerződést a magyarok legnagyobb tragédiájaként, a második helyen, jelentôsen lemaradva az 1956-os forradalom és a megtorlások szerepelt 46\%-kal (2010-es eredmények), illetve 48\%-kal (2012-es ered- 
mények). A zsidóüldözés, deportálás, holokauszt a harmadik helyre került a maga 36\%-ával (2010), illetve 38\%-ával (2012). A magyarok történelmi tudatában - vonja le a következtetést Csepeli (2013a) - Trianon traumája élénken él. Ezt - Karinthy Frigyes Levél címú novellájához hasonlóan - egy szemléletes hasonlattal is érzékelteti: a magyarságukkal erôsen azonosulók számára a békeszerzôdés során elvesztett területek éppen olyan fantomfájdalmat képesek okozni, mint a test számára egy elvesztett végtag. Az elvesztett területekkel ugyanis a nemzeti múlt és kultúra jelentôs részei kerültek el. Trianont a magyar nemzeti identitás sebeként aposztrofálja, amolyan gyógyíthatatlan sérülésként (vö. Volkan, 2001 választott trauma koncepciója). Ezzel egy, a fájdalmától, szenvedéseitôl megszabadulni képtelen, sérülékeny, s így kiszolgáltatott ország képét tárja elénk. Ugyanakkor felhívja a figyelmet arra is, hogy a magyarok megpróbáltatásainak sora itt még nem ér véget; a II. világháború után, a revíziós politika egy rövid, sikeres epizódját követôen Magyarországnak újra le kellett mondania az átmenetileg visszaszerzett területekrôl, ezzel lényegében a magyarság retraumatizálódott, mi több, rávetült az új trauma, a holokauszt, mely ugyanolyan elevenen él a mai magyar társadalomban.

Arra keresvén a választ, hogy mi lehet az oka a magyarság sorozatos rossz döntéseinek és kudarcainak, Ladányi (2015) az önpusztító nemzeti habitus koncepcióját vezeti be. Ez a habitus a csoport történelmi tapasztalatai nyomán alakul ki, azoknak egyfajta produktuma, és mint ilyen, hatással van a soron következó eseményekre adott reakciókra is, befolyásolva a kollektív döntéshozatali és cselekvési folyamatokat, más szavakkal: fontos történelemformáló tényezô is egyben. Szerinte az, hogy egy csoport speciális társadalmi-gazdasági körülményei és kihívásai idôrôl-idôre ismétlődnek, az nagyrészt kollektív habitusával magyarázható. Ez a koncepció, bár az empirikus szociálpszichológia szempontjából nehezen megközelíthetô, és inkább a nemzetkarakterológia homályos területére kalauzol (lásd fentebb, pl. Hunyady, 1997; 2003; 2004), ugyanakkor érdekes adalékul szolgál a nemzetról való elmélkedések irodalmában. Ehhez képest, a magyarokat a történelem során ért sorozatos kudarcok okát Csepeli (1992, 2013b) a magyarok külsố attribúcióra való hajlamában látja, ami megakadályozza az önkritikus következtetések, a hibákból való tanulás lehetôségét.

A magyar nemzeti identitással kapcsolatos pszichológiai tartalmak szisztematikus feltárására vállalkozott a László által vezetett narratív szociálpszichológiai kutatócsoport (pl. Csertô és László, 2011; Fülöp, 2010; Fülöp és László, 2011; Fülöp, Péley és László, 2011; Pólya, Vincze, Fülöp és Ferenczhalmy, 2007; Vincze és László, 2010; lásd összefoglalóan errôl László, 2005; 2012). A narratív tartalomelemzés eszköztárával sor került különbözô korszakokból származó történelemtankönyvek, történelmi regények és néphistóriai elbeszélések elemzésére. Az elvégzett vizsgálatok során kirajzolódó magyar kollektív emlékezet történeti ívét olyan különösen fontosnak ítélt történelmi események alkotják, mint a honfoglalás, a nagy királyok, a törökellenes harcok, a török hódoltság, a Habsburgok elleni harcok, a szabadságharc bukása, az elsô világháború, Trianon, a második világháború, az 1956-os forradalom, a szovjet megszállás és a rendszerváltás (László, Ehmann és Imre, 2002; László, 2005). Ezek alapján egy olyan nemzettörténeti ív tûnik kibontakozni, melyben a dicsố régmúltat javarészt kudarcok sorozata követi, és bár néhány esemény kiemelkedik, végül ezek is vereséggel zárulnak. A történelmi eseményeknek ezt az egymásutániságát László (2005) történelmi 
pályának nevezte el. A kérdés ezzel a történelmi pályával kapcsolatban azonban nem az, hogy „ellentmond-e vagy sem a történészek által feltárt és képviselt realitásnak” (László, 2005), hanem hogy milyen identitás kialakulásához vezet az így megélt történelem. A magyar történelmi pálya központi elemét képezi a külsố csoportok agressziói által való sújtottság ismétlódô tapasztalata. Az áldozattá válás visszatéró élménye egy olyan identitásállapotot eredményezett a magyar nép esetében, amely nagymértékben mutatja a Bar-Tal és munkatársai (2009) által leírt észlelt kollektív áldozatiság jellegzetes mintáját. A narratív pszichológiai tartalomelemzés módszerével, nevezetesen a NarrCat nevú automatizált tartalomelemzô program segítségével - a szövegekben egyebek mellett megjelenô ágenciára, illetve érzelmi és kognitív állapotokra utaló kifejezések gyakorisági előfordulása alapján - tudományos eszközökkel is kimutathatóvá vált, hogy a magyarok történelmi reprezentációit elsôsorban az alacsony ágencia és kontroll mentén lehet jellemezni (Ferenczhalmy, Szalai és László, 2011; Szalai és László, 2007). A magyarok elsôsorban passzív elszenvedôi az eseményeknek, amelyekkel kapcsolatban vonakodnak felelôsséget vállalni: több kognitív állapotot tulajdonítanak a külsố csoportok tagjainak, fôleg a negatív történelmi eseményekkel kapcsolatban, ráadásul ezeknek a „kiutalt” kognitív tartalmaknak a nagy része eleve negatív (Vincze, 2009; Vincze és László, 2010). Ezzel összhangban egy elemzésében Csepeli (2013b) is azt fejtegeti, hogy az ún. „magyar faj” egyik legmeghatározóbb vonása a passzivitás: az elbeszéléseknek nincs cselekvó alanya, a dolgok csak úgy megesnek. Ilyeténképpen az események okai nem a magyarok, ôk csak reagálnak. Éppen ezért a felelôsségvállalás helyett a felelôsséghárítás az, ami jellemzőbb rájuk. Megerôsíteni látszanak mindezt azok a 2010-es és 2013-as közvélemény-kutatási adatok is, melyek szerint a magyar ágenseknek összességében lényegesen kevesebb felelősséget tulajdonítottak a válaszadók, mint a külsố csoportoknak. A két vizsgálat között eltelt három évben ráadásul ebból a szempontból figyelemre méltó, nem túl szerencsés változások is bekövetkeztek: 2010-rôl 2013-ra a magyar lakosságot némileg kevesebben (13\%-ról 9\%), a zsidó lakosságot azonban lényegesen többen (1\%-ról 9\%) tartották felelôsnek a magyarországi holokausztért (Csepeli, 2013a). Az elkövetôi szerep vállalása, különösen egy önmagát - egy korábbi trauma kapcsán - áldozatként definiáló csoport számára olyan mértékben elfogadhatatlan lehet, hogy ez elől csak a tagadás és a felejtés nyújthat menedéket, látszólagos felmentésként pedig az áldozatok hibáztatása és az önsajnálat szolgálhat. Ezzel összhangban a narratív pszichológiai tartalomelemzés egy alapvetôen depresszív dinamikát tükrözó érzelemátélést mutatott ki, mely során a magyaroknak leggyakrabban odaítélt érzelmek: a szomorúság, a csalódottság, a félelem, az irreális remény, valamint a lelkesedés voltak (Fülöp, 2010; Fülöp és László, 2011; László és Fülöp, 2010). Mindezek alapján úgy tûnik, hogy a történelem során a magyarokat ért traumatikus események kognitív és érzelmi feldolgozása elmaradt, nemzeti történelmüket alapvetôen áldozati történetként élik át, ami pedig egy érzelmileg instabil, „sérülékeny nemzeti identitás” (László, 2012) megkonstruálását eredményezte. Ahogy Csepeli (1990) fogalmaz: a magyarok „identitása történelmi traumák, vétkek és bûnök által terhelt, tudattalanja a megvert gyermeké”.

Tanulmányunk utolsó részében azt kívántuk bemutatni, hogy a hazai szociálpszichológiai kutatások alapján miért gondoljuk azt, hogy a magyar kontextusban a kollektív ál- 
dozati identitás jelenségét érdemes vizsgálni. Tanulmányozása közelebb vihet minket annak megértéséhez, hogy mik azok a csoportszinten közösen osztott élmények (vélekedések és érzelmek), amelyek befolyásolják, hogy a csoport tagjai hogyan viszonyulnak a legújabb kori történésekhez, hogyan értelmezik és értékelik saját szerepüket és felelôsségüket az események alakulásában, ezáltal milyen reakciókat, megnyilvánulásokat mutatnak az egyes csoporton belüli és csoportközi eseményekkel kapcsolatban. László (2012) és Csepeli (1990) gondolataival fejezzük be ezt a fejezetet, amelyek világosan bemutatják, hogy a magyar nemzeti identitás és kollektív emlékezet gócpontjaiban traumatikus események állnak, amelyek sérülékeny, instabil nemzeti identitáshoz vezetnek.

\section{MEGVITATÁS}

A csoportközi konfliktusok a szubjektum szintjén bizonyos szempontból mindig a moralitás kérdései körül forognak. Akár elkövetôként, akár áldozatként vesz részt egy csoport a történtekben, az események értelmezése, a reakciók magyarázatai során erkölcsi szempontok is terítékre kerülnek. A csoport által elkövetett erôszakos cselekedetek a csoport morális értékrendjét kérdőjelezik meg, bizonyos feltételek teljesülésekor (errôl részletesebben lásd Wohl, Branscombe és Klar, 2006) egyes csoporttagoknál olyan önkritikus, negatív érzelmek jelennek meg, mint a csoport tetteivel kapcsolatban átélt kollektív bûntudat vagy szégyen, melyek végsố soron a csoportközi kapcsolatok békés rendezése irányába hatnak. Mindez jól magyarázható Nadler és Shnabel (2008; Shnabel és Nadler, 2008) szükségletalapú modelljével, amelynek értelmében az agresszor csoportok elsốdleges célja a pozitív morális identitás helyreállítása, ami a megbánás és a jóvátétel révén tûnik megvalósíthatónak. Ugyanezen modell alapján, az áldozattá vált csoportok számára identitásuk szempontjából cselekvóképességük és ágenciájuk visszaszerzése lesz kulcsfontosságú, ami teljesen más jellegú viselkedést motivál. Az ágencia és erô visszanyerésére ad lehetôséget a bosszú, mely révén a csoport úgy érezheti, hogy „megfizette adósságát”, és helyrebillentette a világ egyensúlyát. Egy csoport áldozati tapasztalatai - az önvédelem igényén és a revans vágyán keresztül - tehát a morális feljogosultság érzéséhez vezethetnek, és erkölcsi szempontból igazolhatóvá, felmenthetôvé teszik a csoport által elkövetett vagy elkövetni kívánt agressziót (pl. Klar, Shori-Eyal és Klar, 2013; Wohl és Branscombe, 2008). Ez végül az áldozat-agresszor körforgáshoz vezethet (pl. Bar-Tal, 2003).

Az áldozati tapasztalatok azonban, ahogyan láthattuk is, nem csupán destruktív kimenetelekhez vezethetnek. Egy csoport - megpróbáltatásainak élményeiból kifolyólag - egyfajta morális felelôsség érzésére is szert tehet, melynek lényege, hogy a csoport tagjai úgy érzik, nem engedhetik, hogy mással is az történjen, ami velük. A holokauszt üzeneteként megfogalmazható „Soha ne hagyd cserben társaidat”, valamint „Soha ne legyél passzív megfigyelôje az eseményeknek" (Klar, Shori-Eyal és Klar, 2013) is ezt a küldetést ragadják meg. De ide tartozik Staub és Vollhardt (2008; Vollhardt és Staub, 2011) „szenvedésbôl született altruizmus” hipotézise is, melyek mind a proszociális segítés szándékát alapozzák meg. Az áldozati tapasztalatok azonban nemcsak a belsô igények szintjén vezethetnek a más áldozatok iránt érzett morális felelősség érzésének 
megjelenéséhez, hanem külsô csoportok elvárásaiként megfogalmazva, amolyan morális kötelességként is ránehezedhetnek az áldozati csoportok vállára.

Hogy egy csoportra áldozati élményei hogyan hatnak, ezeknek milyen viselkedéses következményei lesznek, az egyebek mellett attól is függ, hogy áldozati tapasztalatainak reprezentációjakor milyen élményszervezési mód dominál. A kérdés bizonyos szempontból mindig az, hogy egy csoport a moralitás szabályait hogyan alkalmazza, a saját céljainak alátámasztására, vagy egy szélesebb közjó figyelembevételével. Mint láthattuk, az exkluzív áldozati vélekedések destruktív, az inkluzív áldozati vélekedések inkább konstruktív csoportközi kimeneteket eredményeznek.

Ha figyelembe vesszük, hogy az áldozati identitás kialakitása szempontjából az objektív tapasztalatokon túl a társas konstrukciós folyamatoknak is szerepük van (ld. pl. események értelmezése, a jelentésadás folyamatai), fenntartása pedig különbözô társas és transzgenerációs átöröklési mechanizmusok révén valósul meg, akkor észre kell vennünk a csoport aktív szerepét - ezáltal pedig felelősségének kérdését - önmaga definiálása terén. Ebben jelenthet megoldási lehetôséget az élményszervezés módjában megnyilvánuló különbségek (Vollhardt, 2009a) figyelembevétele. E szerint a csoport szenvedéseinek egyediségét hangsúlyozó exkluzív vélekedések helyett a más csoportok élményei iránt mutatott nyitottságot és empátiát eredményezó inkluzív vélekedések kialakításának támogatása lehetne egy követendó irány.

\section{ÖSSZEGZÉS}

Tanulmányunkban arra vállalkoztunk, hogy a kollektív áldozati identitás jelenségének nemzetközi szakirodalmát mutassuk be. Egy viszonylag új fogalomról van szó, amely körül még sok bizonytalanság és relatíve kevés empirikus eredmény áll. A koncepció bemutatását követően kitértünk azokra a kérdésekre, amelyek a fogalommal kapcsolatban felmerültek, és azokra a dimenziókra, osztályozási szempontokra, amelyek segíthetik a jelenség pontosabb operacionalizálását - hiszen ez elengedhetetlen feltétele a sikeres empirikus munkának. A kollektív áldozati identitás funkcióinak, tüneteinek és következményeinek bemutatása rész valójában arra a kérdésre kereste a választ, hogy miért érdemes ezt a jelenséget kutatni: mi történik egy csoporttal, amelynek tagjai áldozati identitást alakítanak ki, miért marad fenn ez az identitás, és milyen negatív, illetve pozitív következményei lehetnek a csoporton belüli és csoportközi viszonyokat illetốen. Ezt követôen azt mutattuk be, hogy miért releváns a kollektív áldozati identitás kutatása a magyar kontextusban: hogyan jelennek meg az áldozati identitás egyes elemei a magyar szociálpszichológiai munkákban. 


\section{IRODALOM}

Adwan, S. (2001). Schoolbooks in the making: From conflict to peace; A critical analysis of the new Palestinian textbooks for grades one and six. Palestine-Israel Journal of Politics, Economics, and Culture, 8(2), 57-69.

Alexander, J. C., Eyerman, R., Giesen, B., Smelser, N. J., \& Sztompka, P. (2004). Cultural Trauma and Collective Identity. Berkeley, CA: University of California Press.

Asmal K., Asmal, L., \& Roberts, R. S. (1997). Reconciliation through Truth: A reckoning of Apartheid's Criminal Governance. Capetown: David Phillips Publishers.

Barkan, E. (2000). The Guilt of Nations. London: W. W. Norton.

Bar-Tal, D. (2001). Why does fear override hope in societies engulfed by intractable conflicts as it does in Israeli society? Political Psychology, 22, 601-627.

Bar-Tal, D. (2003). Collective memory of physical violence: Its contribution to the culture of violence. In: E. Cairns, \& M. D. Roe (Eds), The Role of Memory in Ethnic Conflict (77-93). UK: Palgrave Macmillan.

Bar-Tal, D., \& Antebi, D. (1992a). Beliefs about negative intentions of the world: A study of the Israeli siege mentality. Political Psychology, 13(4), 633-645.

Bar-Tal, D., \& Antebi, D. (1992b). Siege mentality in Israel. International Journal of Intercultural Relations, 16, 251-275.

Bar-Tal, D., \& Cehajic-Clancy, S. (2014). From collective victimhood to social reconciliation: Outlining a conceptual framework. In War, Community, and Social Change (125-136). New York: Springer.

Bar-Tal, D., Chernyak-Hai, L., Schori, N., \& Gundar, A. (2009). A sense of self-perceived collective victimhood in intractable conflicts. International Review of the Red Cross, 91(874), 229-258.

Baumeister, R. F., \& Hastings, S. (1997). Distortions of Collective Memory: How Groups Flatter and Deceive Themselves. (277-293) In: Pennebaker, J. W., Paez, D., \& Rimé, B. (Eds), Collective Memory of Political Events: Social Psychological Perspectives. Hillsdale, NJ: Lawrence Erlbaum.

Bilali, R. (2012). Identity centrality and in-group superiority differentially predict reactions to historical victimization and harm doing. International Journal of Conflict and Violence, 6, 322-338.

Bilali, R., \& Vollhardt, J. R. (2013). Priming effects of a reconciliation radio drama on historical perspective-taking in the aftermath of mass violence in Rwanda. Journal of Experimental Social Psychology, 49(1), 144-151.

Bilewicz, M., \& Jaworska, M. (2013). Reconciliation through the righteous: The narratives of heroic helpers as a fulfillment of emotional needs in Polish-Jewish intergroup contact. Journal of Social Issues, 69(1), 162-179.

Bruckner, P. (2010). The Tyranny of Guilt: An Essay on Western Masochism. Princeton, NJ: Princeton University Press.

Cohrs, J. C., McNeill, A., \& Vollhardt, J. R. (2015). The two-sided role of inclusive victimhood for intergroup reconciliation: Evidence from Northern Ireland. Peace and Conflict. Journal of Peace Psychology, 21, 634-647.

Connerton, P. (1989). How Societies Remember. Cambridge, UK: Cambridge University Press.

Crownshaw, R. (2007). Photography and memory in Holocaust museums. Mortality, 12(2), 176-192.

Csepeli, GY. (1990). „Nemzeti tudattalan.” Thalassa, Vol. I. No. 1. 43-46.

Csepeli, GY. (1992). Nemzet által homályosan. Budapest: Századvéd Kiadó.

Csepeli, GY. (2002). A nagyvilágon e kíü̈l.. Nemzeti tudat és érzésvilág Magyarországon 1970-2002. Budapest: Jószöveg Kiadó. 
Csepeli Gy. (2013a). Nemzeti emlékezet, nemzeti felejtés. A Történelemtanárok Egylete által szervezett Mire emlékszünk? A közösségi memória szelektivitása Magyarországon és a nagyvilágban címú konferencián elhangzott elôadás bôvített, írásos változata. Letöltve: 2016. január 24. http:/ / www.tte.hu/media/pdf/nemzeti_emlekezet.pdf

Csepeli Gy. (2013b). A magyar faj abszurditása (Prolegomena egy hasonló címú, tervezett könyvhöz). Mozgó Világ, 39(1).

Csepeli, Gy., \& Örkény A. (1996). A nemzeti büszkeség könnyúsége. Élet és Irodalom, 1996. 07. 05. Letöltve: 2016. február 2. http://www.csepeli.hu/pub/1996/csepeli_orkeny_ es_1996_07_05.pdf

Csepeli Gy., Örkény A., Székelyi M., \& Poór J. (2004). Nemzeti identitás Magyarországon az ezredfordulón. Társadalmi Riport, 8(1), 471-483.

Csertố I., \& László J. (2011). A csoportközi értékelés mint a csoporttrauma érzelmi feldolgozásának indikátora a nemzetközi történelem elbeszéléseiben. In Tanács A., Vincze V. (szerk.) VIII. Magyar Számítógépes Nyelvészeti Konferencia: MSZNY 2011 (212-222). Szeged: Szegedi Tudományegyetem Informatikai Tanszékcsoport.

Danielidou, L., \& Horvath, P. (2006). Greek cypriot attitudes toward Turkish cypriots and Turkish immigrants. The Journal of Social Psychology, 146(4), 405-421.

Degloma, T. (2009). Expanding trauma through space and time: Mapping the rhetorical strategies of trauma carrier groups. Social Psychology Quarterly, 72, 105-122.

Doosje, B., Branscombe, N. R., Spears, R., \& Manstead, A. S. R. (1998). Guilt by association: when one's group has a negative history. Journal of Personality and Social Psychology, 75, 872-886.

Dresler-Hawke, E., \& Liu, J. H. (2006). Collective shame and the positioning of German national identity. Psicologica Politicia, 32, 131-153.

Dumont, M., Yzerbyt, V., Wigboldus, D. L., \& Gordijn, E. H. (2003). Social categorization and fear reactions to the September 11th terrorist attacks. Personality and Social Psychology Bulletin, 29, 1509-1520.

Elcheroth, G. (2006). Individual-level and community-level effects of war trauma on social representations related to humanitarian law. European Journal of Social Psychology, 36, 907-930.

Erôs, F. (2001). Az identitás labirintusai. Narratív konstrukciók és identitás-stratégiák. Budapest: Osiris Kiadó.

Erôs, F. (2007). Trauma és történelem - Szociálpszichológiai és pszichoanalitikus tanulmányok. Budapest: Jószöveg Múhely Kiadó.

Fasel, R., \& Spini, D. (2010). Effects of Victimization on the Belief in a Just World in Four ExYugoslavian Countries. Social Justice Research, 23(1), 17-36. doi:10.1007/s11211-010-0111-6

Feldman, J. (2007). Between Yad Vashem and Mt. Herzl: Changing inscriptions of sacrifice on Jerusalem's "Mountain of Memory". Anthropological Quarterly, 80, 1147-1174.

Ferenczhalmy R., Szalai K., \& László J. (2011). Az ágencia szerepe történelmi szövegekben a nemzeti identitás szempontjából. Pszichológia, 1, 35-46.

Fernández, S., Branscombe, N. R., Saguy, T., Gómez, Á., \& Morales, J. F. (2014). Higher moral obligations of tolerance toward other minorities an extra burden on stigmatized groups. Personality and Social Psychology Bulletin, 40(3), 363-376.

Fülöp, É. (2010). A történelmi pálya és a nemzeti identitás érzelmi szervezôdése. PhD-értekezés. Pécsi Tudományegyetem Bölcsészettudományi Kar Pszichológia Doktori Iskola Szociálpszichológia Program.

Fülöp É., \& László J. (2011). Érzelmek a valós csoportközi konfliktusokban: a csoportközi érzelmek történelmi lehorgonyzása. Magyar Pszichológiai Szemle, 66(3), 467-486.

Fülöp É., Péley B., \& László J. (2011). A történelmi pályához kapcsolódó érzelmek modellje magyar történelmi regényekben. Pszichológia, 31(1), 47-67. 
Gómez, Á., Dovidio, J. F., Gaertner, S. L., Fernández, S., \& Vázquez, A. (2013). Responses to Endorsement of Commonality by Ingroup and Outgroup Members The Roles of Group Representation and Threat. Personality and Social Psychology Bulletin, 39(4), 419-431.

Goodman, Y. C., \& Mizrachi, N. (2008). "The Holocaust does not belong to European Jews alone": The differential use of memory techniques in Israeli high schools. American Ethnologist, 35(1), 95-114.

Halperin, E., \& Bar-Tal, D. (2011). Socio-psychological barriers to peace making: An empirical examination within the Israeli Jewish society. Journal of Peace Research, 48(5), 637-651.

Halperin, E., Bar-Tal, D., Nets-Zehngut, R., \& Drori, E. (2008). Emotions in conflict: Correlates of fear and hope in the Israeli-Jewish society. Peace and Conflict: Journal of Peace Psychology, 14(3), 233-258.

Hammack, P. L. (2009). Exploring the reproduction of conflict through narrative: Israeli youth motivated to participate in a coexistence program. Peace and Conflict: Journal of Peace Psychology, 15, 49-74.

Hayes, G. (1998). We suffer our memories: Thinking about the past, healing, and reconciliation. American Imago, 55, 29-50.

Hayner, P. B. (1999). In pursuit of justice and reconciliation: Contributions of truth telling. In Arnson, C. J. (Ed.) Comparative peace processes in Latin America (363-383). Stanford: Stanford University Press.

Hernandez-Wolfe, P. (2011). Altruism born of suffering: How Colombian human rights activists transform pain into prosocial action. Journal of Humanistic Psychology, 51(2), 229-249.

Hopkins, N., Reicher, S., Harrison, K., Cassidy, C., Bull, R., \& Levine, M. (2007). Helping to improve the group stereotype: On the strategic dimension of prosocial behavior. Personality and Social Psychology Bulletin, 33(6), 776-788.

Hunyady Gy. (1997). A nemzeti identitás és a sztereotípiák görbe tükre. Új Pedagógiai Szemle, $47(10), 45-59$.

Hunyady Gy. (2003). Nemzetkarakterológiák. Budapest: Osiris Kiadó.

Hunyady Gy. (2004). A nemzetek jellemzése és a nemzeti sztereotípiák. Elóadás a Mindentudás Egyetemén. http://mindentudas.hu/elodasok-cikkek/item/32-a-nemzetekjelleme-\%C3\%A9s-a-nemzeti-sztereot\%C3\%ADpi\%C3\%A1k.html

Ignatieff, M. (1993). The Balkan Tragedy. The New York Review of Books, 40(9), (May 13, 1993), $3-5$.

Janoff-Bulman, R. (1992). Shattered assumptions: Towards a new psychology of trauma. New York: Free Press.

Jetten, J., Branscombe, N. R., Schmitt, M. T., \& Spears, R. (2001). Rebels with a cause: Group identification as a response to perceived discrimination from the mainstream. Personality and Social Psychology Bulletin, 27(9), 1204-1213.

Kahana, B., Kahana, E., Harel, Z., \& Segal, M. (1985). The victim as helper: Prosocial behavior during the Holocaust. Humboldt Journal of Social Relations, 13, 357-373.

Khalili, L. (2007). Heroes and martyrs of Palestine—The politics of national commemoration. New York: Cambridge University Press.

Khalili, L. (2008). Commemorating battles and massacres in the Palestinian refugee camps of Lebanon. American Behavioral Scientist, 51, 1562-1574.

Kessler, T., \& Hollbach, S. (2005). Group-based emotions as determinants of ingroup identification. Journal of Experimental Social Psychology, 41(6), 677-685.

Klar, Y., Schori-Eyal, N., \& Klar, Y. (2013). The "never again" state of Israel: The emergence of the Holocaust as a core feature of Israeli identity and its four incongruent voices. Journal of Social Issues, 69(1), 125-143. 
Kopstein, J. S. (1997). The politics of national reconciliation: Memory and institutions in German-Czech relations since 1989. Nationalism E Ethnic Politics, 3, 51-78.

Kovács J., \& Pántya J. (2012). A vesztes-szerep mintázatai magyar történelmi események értékelésében. In Kovács J., \& Münnich Á. (szerk.) Nemzeti emlékezethelyek: attitüdök, reprezentációk, élmények, funkciók, struktúrák (33-56). Debrecen: Debreceni Egyetemi Kiadó.

Kurtiş, T., Adams, G., \& Yellow-Bird, M. (2010). Generosity or genocide? Identity implications of silence in American Thanksgiving commemorations. Memory, 18(2), 208-224.

Ladányi J. (2015). Önpusztító nemzeti habitus. Budapest: L'Harmattan Kiadó.

Lang, B. (1996). Holocaust memory and revenge: The presence of the past. Jewish Social Studies, $2(2), 1-20$.

László, J. (2003). History, identity and narratives. In László, J., \& Wagner, W. (Eds), Theories and Controversies in Societal Psychology. (180-192) Budapest: New Mandate.

László J. (2005). A történetek tudománya: Bevezetés a narratív pszichológiába. Pszichológiai Horizont 3. Budapest: Új Mandátum.

László J. (2012). Történelem-történetek. Bevezetés a narratív szociálpszichológiába. Budapest: Akadémiai Kiadó.

László J., Ehmann B., \& Imre O. (2002). Történelem Történetek: A történelem szociális reprezentációja és a nemzeti identitás. Pszichológia, 22(2), 147-161.

László J., \& Fülöp É. (2010). A történelem érzelmi reprezentációja a történelemkönyvekben és naiv elbeszélésekben. Történelemtanitás, XLV. évfolyam, 1/3.

László J., \& Fülöp É. (2011). Nemzeti identitás és kollektív áldozati szerep. Pszichológia, 31(3), 295-315.

Leach, C. W., Van Zomeren, M., Zebel, S., Vliek, M. L. W., Pennekamp, S. F., Doosje, B., Ouwerkerk, J. W., \& Spears, R. (2008). Group-level self-definition and self-investment: a hierarchical (multicomponent) model of in-group identification. Journal of Personality and Social Psychology, 95, 144-165.

Licata, L., \& Klein, O. (2010). Holocaust or benevolent paternalism? Intergenerational comparisons on collective memories and emotions about Belgium's colonial past. International Journal of Conflict and Violence, 4(1), 46.

Lickel, B., Miller, N., Stenstrom, D. M., Denson, T. F., \& Schmader, T. (2006). Vicarious retribution: The role of collective blame in intergroup aggression. Personality and Social Psychology Review, 10, 372-390.

Lifton, R. J. (1967). Death in life. Survivors of Hiroshima. New York: Vintage.

Lifton, R. J. (2003). American apocalypse. The Nation, 277(21), 11-17.

Liu, J. H., \& Hilton, D. J. (2005). How the Past Weighs on the Present: Social Representations of History and their Role in Identity Politics. British Journal of Social Psychology, 44(4), 537-556.

Liu, J. H., \& László, J. (2007). A narrative theory of history and identity. In Social Representations and Identity (85-107). Palgrave Macmillan US.

Lomsky-Feder, E. (2004). The memorial ceremony in Israeli schools: between the State and civil society. British Journal of Sociology of Education, 25(3), 291-305.

MacDonald, D. B. (2003). Balkan Holocausts? Serbian and Croatian victim centered propaganda and the war in Yugoslavia. Manchester, UK: Manchester University Press.

Mack, J. (1990). The psychodynamics of victimization among national groups in conflict. In: V. Volkan, D. Julius \& J. Montville (Eds), The psychodynamics of international relationships (vol. 1) (119-129). Concepts and theories. Toronto, ON: Lexington Books.

Manzi, J., \& Gonzalez, R. (2007). Forgiveness and reparation in Chile: The role of cognitive and emotional intergroup antecedents. Peace and Conflict: Journal of Peace Psychology, 13, 71-91.

Maoz, I., \& Bar-On, D. (2002). From working through the Holocaust to current ethnic conflicts: Evaluating the TRT group workshop in Hamburg. Group, 26, 29-48. 
Maoz, I., \& Eidelson, R. J. (2007). Psychological bases of extreme policy preferences: How the personal beliefs of Israeli-Jews predict their support for population transfer in the Israeli-Palestinian conflict. American Behavioral Scientist, 50, 1476-1497.

McGarty, C., Pedersen, A., Leach, C. W., Mansell, T., Waller, J., \& Bliuc, A. M. (2005). Groupbased guilt as a predictor of commitment to apology. British Journal of Social Psychology, 44, $659-680$.

Mészáros N. Zs., Szabó Zs. P., \& László J. (2013). Consensus and differences in the judgment of historical events. In P. Cunningham (Ed.), Identities and Citizenship Education: Controversy, Crisis and Challenges: Selected papers from the fifteenth Conference of the Children's Identity and Citizenship in Europe Academic Network (656-668). London: CiCe - London Metropolitan University.

Nadler, A., \& Shnabel, N. (2008). Instrumental and socioemotional paths to intergroup reconciliation and the needs-based model of socioemotional reconciliation. The social psychology of intergroup reconciliation, 37-56.

Nair, R., \& Vollhardt, J. R. (2012). "We feel your pain, and we've been there, too": Expressions of solidarity between minority groups in India. Presented at the annual meeting of the International Society of Political Psychology, July 6-9 Chicago, IL.

Noor, M., Brown, R., Gonzalez, R., Manzi, J., \& Lewis, C. A. (2008). On positive psychological outcomes: What helps groups with a history of conflict to forgive and reconcile with each other? Personality and Social Psychology Bulletin, 34, 819-832.

Noor, M., Brown, R., \& Prentice, G. (2008). Prospects for intergroup reconciliation: Socialpsychological predictors of intergroup forgiveness and reparation in Northern Ireland and Chile. The social psychology of intergroup reconciliation, 97-114.

Noor, M., Shnabel, N., Halabi, S., \& Nadler, A. (2012). When suffering begets suffering: The psychology of competitive victimhood between adversarial groups in violent conflicts. Personality and Social Psychology Review, 16, 351-374.

Nora, P. (2010). Emlékezet és történelem között. Válogatott tanulmányok. Budapest: Napvilág Kiadó.

Norval, A. J. (1998). Memory, identity and the (im) possibility of reconciliation: The work of the Truth and Reconciliation Commission in South Africa. Constellations, 5, 250-265.

Norval, A. J. (1999). Truth and reconciliation: The birth of the present and the reworking of history. Journal of African Studies, 25, 499-519.

Olick, J. K., \& Robbins, J. (1998). Social memory studies: From "collective memory" to the historical sociology of mnemonic practices. Annual Review of Sociology, 105-140.

Paez, D. (2010). Official or political apologies and improvement of intergroup relations: A neo-Durkheimian approach to official apologies as rituals. Revista de Psicología Social, $25(1), 101-115$.

Pataki F. (2011). A varázsát vesztett jövố. Budapest: Noran Libro Kiadó.

Pataki F., \& Ritoók Zs. (szerk.) (1999). Magyarságkép és történeti változásai. Magyarország az ezredfordulón. Budapest: MTA.

Pennekamp, S. F., Doosje, B., Zebel, S., \& Fischer, A. H. (2007). The past and the pending: The antecedents and consequences of group-based anger in historically and currently disadvantaged groups. Group Processes and Intergroup Relations, 10, 41-55.

Pettigrew, T. F. (2003). Peoples under threat: Americans, Arabs, and Israelis. Peace and Conflict: Journal of Peace Psychology, 9, 69-90.

Pólya T., Vincze O., Fülöp É., \& Ferenczhalmy R. (2007). Az idői perspektíva előfordulása történelmi tankönyvi szövegekben. In MSZNY 2007, V. Magyar Számítógépes Nyelvészeti Konferencia. Szeged: Szegedi Tudományegyetem Informatikai Tanszékcsoport, 235-241.

Power, S. (1999). To suffer by comparison? Daedalus, 128(2), 31-66. 
Raboteg-Saric, Z., Zuzul, M., \& Kerestes, G. (1994). War and children's aggressive and prosocial behaviour. European Journal of Personality, 8, 210-212.

Ramanathapillai, R. (2006). The politicizing of trauma: A case study of Sri Lanka. Peace and Conflict. Journal of Peace Psychology, 12, 1-18.

Rice, C. A., \& Benson, J. F. (2005). Hungering for revenge: The Irish famine, the troubles and shame-rage cycles, and their role in group therapy in Northern Ireland. Group Analysis, 38(2), 219-235.

Ricoeur, P. (2006). Emlékezet - felejtés - történelem. In Gyurgyák J., \& Kisantal T. (szerk.), Történelemelmélet I. (108-122.) Budapest: Osiris Kiadó.

Rimé, B., Bouchat, P., Klein, O., \& Licata, L. (2015). When collective memories of victimhood fade: Generational evolution of intergroup attitudes and political aspirations in Belgium. European Journal of Social Psychology, 45(4), 515-532.

Roccas, S., Klar, Y., \& Liviatan, I. (2006). The paradox of group-based guilt: modes of national identification, conflict vehemence, and reactions to the in-group's moral violations. Journal of Personality and Social Psychology, 91, 698-711.

Roccas, S., Sagiv, L., Schwartz, S., Halevy, N., \& Eidelson, R. (2008). Toward a Unifying Model of Identification with Groups: Integrating Theoretical Perspectives. Personality and Social Psychology Review, 12(3), 280-306.

Sahdra, B., \& Ross, M. (2007). Group Identification and Historical Memory. Personality and Social Psychology Bulletin, 33(3), 384-395.

Salomon, G. (2004). A narrative-based view of coexistence education. Journal of Social Issues, 60(2), 273-281.

Sani, F., Bowe, M., Herrera, M., Manna, C., Cossa, T., Miao, X., \& Zhou, Y. (2007). Perceived collective continuity: Seeing groups as entities that move through time. European Journal of Social Psychology, 37(6), 1118-1134.

Schmitt, M. T., \& Branscombe, N. R. (2002). The meaning and consequences of perceived discrimination in disadvantaged and privileged social groups. European review of social psychology, 12(1), 167-199.

Schori, N., Klar, Y., \& Roccas, S. (2009). In every generation, they rise up against us to annihilate us: Perpetual Ingroup Victimhood Orientation (PIVO) and behavior in a current intergroup conflict. In 32nd Annual Meeting of the International Society for Political Psychology, Dublin (Ireland).

Schori-Eyal, N. (2011). The shadows of the past: Effects of historical group trauma on current intergroup conflicts. Doctoral Dissertation. Tel-Aviv, Israel: Tel-Aviv University.

Serotta, E. (1994). Survival in Sarajevo. How a Jewish Community Came to the Aid of Its City. Vienna, Austria: Brandstaedtter.

Sherif, M. (1956). Experiments in group conflict. Readings about the social animal. 344-353.

Sherif, M., Harvey, O. J., White, B. J., Hood, W. R., \& Sherif, C. W. (1961). Intergroup conflict and cooperation: The Robbers Cave experiment (Vol. 10, 150-198). Norman, OK: University Book Exchange.

Shnabel, N., \& Nadler, A. (2008). A needs-based model of reconciliation: satisfying the differential emotional needs of victim and perpetrator as a key to promoting reconciliation. Journal of Personality and Social Psychology, 94(1), 116.

Simantov-Nachlieli, I., \& Shnabel, N. (2014). Feeling Both Victim and Perpetrator: Investigating Duality Within the Needs-Based Model. Personality and Social Psychology Bulletin, 40, 301-314.

Simon, B., \& Klandermans, B. (2001). Politicized collective identity: A social psychological analysis. American Psychologist, 56(4), 319-331. 
Suedfeld, P. (1999). Toward a taxonomy of ethnopolitical violence: Is collective killing by any other name still the same? Peace and Conflict: Journal of Peace Psychology, 5, 349-355.

Sullivan, D., Landau, M. J., Branscombe, N. R., \& Rothschild, Z. K. (2012). Competitive victimhood as a response to accusations of ingroup harm doing. Journal of Personality and Social Psychology, 102(4), 778-795.

Staub, E. (1998). Breaking the cycle of genocidal violence: Healing and reconciliation. In Harvey, J. H. (Ed.) Perspectives on Loss: A Sourcebook. Death, Dying, and Bereavement (231-238). Philadelphia, PA, US: Brunner/Mazel.

Staub, E. (2003). The Psychology of Good and Evil: Why Children, Adults, and Groups Help and Harm Others. Cambridge, MA: Cambridge University Press.

Staub, E. (2005). The roots of goodness: The fulfillment of basic human needs and the development of caring, helping and nonaggression, inclusive caring, moral courage, active bystandership, and altruism born of suffering. In G. Carlo \& C. Edwards (Eds), Nebraska Symposium on Motivation: Vol. 51. Moral Motivation through the Life Span: Theory, Research, Applications. Lincoln: University of Nebraska Press.

Staub, E., \& Bar-Tal, D. (2003). Genocide, mass killing and intractable conflict: Roots, evolution, prevention and reconciliation. In Sears, D. O., Huddy, L., Jervis, R. (Eds), Oxford Handbook of Political Psychology (710-751). New York, NY, US: Oxford University Press.

Staub, E., \& Vollhardt, J. (2008). Altruism born of suffering: The roots of caring and helping after victimization and other trauma. American Journal of Orthopsychiatry, 78(3), 267-280.

Stern, P. C. (1995). Why do people sacrifice for their nations? Political Psychology, 16, 217-235.

Szabó Zs. P. (2013). A nemzeti csoporttal való azonosulás hatása a csoportalapú érzelmek átélésére. PhD-értekezés. Pécs: Pécsi Tudományegyetem Bölcsészettudományi Kar Pszichológia Doktori Iskola.

Szabó Zs. P., Banga Cs., Fülöp É., \& László J. (2011). A csoportalapú érzelmek kutatása a szociálpszichológiában. Magyar Pszichológiai Szemle, 66(2), 361-380.

Szalai K., \& László J. (2007). Az aktív és passzív igék gyakorisága a csoportjelenségek tükrében. In: MSZNY 2007 V. Magyar Számítógépes Nyelvészeti Konferencia. Szeged: Szegedi Tudományegyetem Informatikai Tanszékcsoport. 2007. december 6-7. 242-249.

Tajfel, H. (1982). The social psychology of intergroup relations. Annual Review of Psychology, 33, 1-39.

Tamari, S. (2002). Narratives of exile. Palestine-Israel Journal, 9(4), 101-109. Letöltve: 2016. január 10. http://www.pij.org/details.php?id=113

Thomsen, L., Green, E., Ho, A. K., Levin, S., Van Laar, C., Sinclair, S., \& Sidanius, J. (2010). Wolves in sheep's clothing: SDO asymmetrically predicts perceived ethnic victimization among white and Latino students across three years. Personality and Social Psychology Bulletin, 36, 225-238.

Tóth J., Vincze O., \& László J. (2006). Történelmi elbeszélés és nemzeti identitás. Az Osztrák-Magyar Monarchia reprezentációja osztrák és magyar történelemkönyvekben. Educatio, 15(1), 174-182.

Trope, Y., \& Liberman, N. (2003). Temporal construal. Psychological Review, 110, 403-421.

Turner, J. C., Hogg, M. A., Oakes, P. J., Reicher, S. D., \& Wetherell, M. S. (1987). Rediscovering the social group: A self-categorization theory. Oxford and New York: Basil Blackwell.

Updegraff, J. A., Silver, R. C., \& Holman, E. A. (2008). Searching for and finding meaning in collective trauma: Results from a national longitudinal study of the $9 / 11$ terrorist attacks. Journal of Personality and Social Psychology, 95, 709-722.

Van Leeuwen, E., \& Mashuri, A. (2013). Intergroup helping in response to separatism. Personality and Social Psychology Bulletin, 39(12), 1647-1655. 
Vincze O. (2009). Mentális állapotok jelentôsége csoporttörténetekben a saját és a külsố csoport vonatkozásában. PhD-értekezés. Pécsi Tudományegyetem Bölcsészettudományi Kar Pszichológia Doktori Iskola Szociálpszichológia Program.

Vincze O., \& Kôváriné Somogyvári I. (2003). A nemzeti identitás reprezentációja a sikeres történelmi regényekben. Magyar Tudomány, 1, 58-66.

Vincze O., \& László J. (2010) A narratív perspektíva szerepe a történelemkönyvekben. Magyar Pszichológiai Szemle, 65(4), 571-595.

Volkan, V. D. (2001). Transgenerational transmissions and chosen traumas: An aspect of largegroup identity. Group Analysis, 34, 79-97.

Volkan, V. D. (2006). Large-group identity, large-group regression and massive violence. GroupAnalytic Contexts, 30, 8-26.

Vollhardt, J. R. (2009a). The role of victim beliefs in the Israeli-Palestinian conflict: Risk or potential for peace? Peace and Conflict: Journal of Peace Psychology, 15(2), 135-159.

Vollhardt, J. R. (2009b). Altruism born of suffering and prosocial behavior following adverse life events: A review and conceptualization. Social Justice Research, 22, 53-97.

Vollhardt, J. R. (2012). Collective victimization. In L. R. Tropp (Ed.), The Oxford Handbook of Intergroup Conflict (136-157) New York, NY: Oxford University Press.

Vollhardt, J. R. (2013). "Crime against humanity" or "Crime against Jews"? Acknowledgment in construals of the holocaust and its importance for intergroup relations. Journal of Social Issues, 69, 144-161.

Vollhardt, J. R. (2015). Inclusive victim consciousness in advocacy, social movements, and intergroup relations: Promises and pitfalls. Social Issues and Policy Review, 9, 86-117.

Vollhardt, J. R., \& Bilali, R. (2015). The role of inclusive and exclusive victim consciousness in predicting intergroup attitudes: Findings from Rwanda, Burundi, and DRC. Political Psychology, 36, 489-506.

Vollhardt, J. R., Nair, R., \& Tropp, L. R. (2016). Inclusive victim consciousness predicts minority group members' support for refugees and immigrants. Journal of Applied Social Psychology, 46, 354-368.

Vollhardt, J., \& Staub, E. (2011). Inclusive altruism born of suffering: The relationship between adversity and prosocial attitudes and behavior toward disadvantaged outgroups. The American Journal of Orthopsychiatry, 81, 307-315.

Warner, R. H., \& Branscombe, N. R. (2012). Observer perceptions of moral obligations in groups with a history of victimization. Personality and Social Psychology Bulletin, 38(7), 882-894.

Wayment, H. A. (2004). It could have been me: Vicarious victims and disaster-focused distress. Personality and Social Psychology Bulletin, 30, 515-528.

WHO (2002). World Report on Violence and Health. Geneva: World Health Organization.

Wohl, M. J., \& Branscombe, N. R. (2005). Forgiveness and collective guilt assignment to historical perpetrator groups depend on level of social category inclusiveness. Journal of Personality and Social Psychology, 88(2), 288.

Wohl, M. J., \& Branscombe, N. R. (2008). Remembering historical victimization: Collective guilt for current ingroup transgressions. Journal of Personality and Social Psychology, 94, 988-1006.

Wohl, M. J., Branscombe, N. R., \& Klar, Y. (2006). Collective guilt: emotional reactions when one's group has done wrong or been wronged. European Review of Social Psychology, 17, 1-36.

Wohl, M. J., Branscombe, N. R., \& Reysen, S. (2010). Perceiving your group's future to be in jeopardy: Extinction threat induces collective angst and the desire to strengthen the ingroup. Personality and Social Psychology Bulletin, 36, 898-910.

Yildiz, A., \& Verkuyten, M. (2011). Inclusive victimhood: Social identity and the politicization of collective trauma among Turkey's Alevis in Western Europe. Peace and Conflict: Journal of Peace Psychology, 17(3), 243-269. 
INSTABLE IDENTITY

\title{
THE PSYCHOLOGICAL EFFECTS OF COLLECTIVE VICTIM CONSCIOUSNESS
}

\author{
MÉSZÁROS, NOÉMI ZSUZSANNA - VÁMOS, ESZTER - SZABÓ, ZSOLT PÉTER
}

In this overview we intend to give a Hungarian summary of the phenomenon of collective victim consciousness. We can talk about collective victim consciousness, if there is a shared belief among group members that the in-group is exposed to harm by other groups. These harms are judged to be undeserved and unjust as well as immoral and intentional, which the group cannot prevent, so group members feel vulnerable. This type of identity construal has a significant effect not only on the internal mechanisms and future of the in-group, but on the relations with other groups as well.

Describing the phenomenon of collective victim consciousness we discuss the problems associated with the definition and operationalization of the concept. Determinative dimensions of collective victimization, the mechanisms of maintaining and passing on collective victimhood identity, also the functions and consequences of victim identity construal are presented.

Finally, the so-called Hungarian victim identity resulted from the characteristics of Hungarian historical trajectory is discussed in the light of social scientific theories and researches of the last years and decades.

Keywords: perceived collective victim consciousness, national identity, exclusive - inclusive victim consciousness, competitive victimhood 